NBER WORKING PAPER SERIES

\title{
RUGGED INDIVIDUALISM AND COLLECTIVE (IN)ACTION DURING THE COVID-19 PANDEMIC
}

\author{
Samuel Bazzi \\ Martin Fiszbein \\ Mesay Gebresilasse \\ Working Paper 27776 \\ http://www.nber.org/papers/w27776 \\ NATIONAL BUREAU OF ECONOMIC RESEARCH \\ 1050 Massachusetts Avenue \\ Cambridge, MA 02138 \\ September 2020
}

We thank Austin Wright for sharing data. All errors are our own. The views expressed herein are those of the authors and do not necessarily reflect the views of the National Bureau of Economic Research.

NBER working papers are circulated for discussion and comment purposes. They have not been peer-reviewed or been subject to the review by the NBER Board of Directors that accompanies official NBER publications.

(C) 2020 by Samuel Bazzi, Martin Fiszbein, and Mesay Gebresilasse. All rights reserved. Short sections of text, not to exceed two paragraphs, may be quoted without explicit permission provided that full credit, including $\odot$ notice, is given to the source. 
Rugged Individualism and Collective (In)action During the COVID-19 Pandemic

Samuel Bazzi, Martin Fiszbein, and Mesay Gebresilasse

NBER Working Paper No. 27776

September 2020

JEL No. H12,H23,H75,I12,I18,P16

\section{$\underline{\text { ABSTRACT }}$}

Rugged individualism - the combination of individualism and anti-statism - is a prominent feature of American culture with deep roots in the country's history of frontier settlement. Today, rugged individualism is more prevalent in counties with greater total frontier experience (TFE) during the era of westward expansion. While individualism may be conducive to innovation, it can also undermine collective action, with potentially adverse social consequences. We show that America's frontier culture hampered the response to the COVID-19 pandemic. Across U.S. counties, greater TFE is associated with less social distancing and mask use as well as weaker local government effort to control the virus. We argue that frontier culture lies at the root of several more proximate explanations for the weak collective response to public health risks, including a lack of civic duty, partisanship, and distrust in science.

Samuel Bazzi

Department of Economics

Boston University

270 Bay State Road

Boston, MA 02215

and CEPR

and also NBER

sbazzi@bu.edu

Martin Fiszbein

Department of Economics

Boston University

270 Bay State Road

Boston, MA 02215

and NBER

fiszbein@bu.edu
Mesay Gebresilasse

Amherst College

301 Converse Hall

Amherst, MA 01002

mgebresilasse@amherst.edu 


\section{Introduction}

Individualism is often associated with resourcefulness and innovation. However, it may also hinder collective action. In the context of infectious disease epidemics, non-pharmaceutical interventions (NPIs) like social distancing and mask use can be key components of effective public health responses. During the COVID-19 pandemic, adoption of these practices has varied widely across and within countries. This variation has important consequences for the spread of the virus, but its origins remain widely debated. We argue that individualism is an important driving factor.

This paper shows that America's culture of rugged individualism-the combination of individualism and opposition to government intervention-undermined collective action against COVID-19. The public health response to COVID-19 has been significantly weaker in U.S. localities with a longer frontier history, which Bazzi et al. (forthcoming) identify as a key driver of rugged individualism.

During the process of westward expansion that marked the early history of the U.S., the frontier rewarded independence and self-reliance. Frontier settlers had opportunities for upward mobility but also faced significant challenges, with little social infrastructure to turn to. As suggested by Turner (1893), frontier locations were historically more individualistic. Our prior work shows that this distinctive culture persisted: localities that spent more time on the frontier exhibit greater individualism and anti-statism in the long run. Rugged individualism cuts across known cultural divides in the U.S., including urban-rural and north-south, and thus sheds new light on the stark geographic variation in opposition to effective public health efforts to contain COVID-19.

We identify a weaker response to the pandemic in counties with greater total frontier experience (TFE, the duration of exposure to frontier conditions historically). This can be seen in the responses of residents as well as local governments. We measure social distancing with mobility data before and after the national pandemic declaration on March 13, 2020, estimating event-study specifications with county fixed effects. While high- and low-TFE counties exhibit little difference in mobility before this date, a sharp differential emerges thereafter as residents of high-TFE counties are less likely to avoid non-essential trips outside the home.

We also find that greater TFE is associated with less use of face masks in public space, another important response to curb infectious disease transmission. Residents in high-TFE counties are significantly more likely to report never, rarely, or only sometimes using masks when outside the home. While this outcome is only observed in early July 2020, the stark cross-sectional differences in mask use are consistent with the event-study results on social distancing.

The negative influence of TFE on social distancing and mask use is not due to confounding demographic and climatic differences. We consider a host of factors emphasized in prior work on COVID-19, including population density, temperature, income, education, and racial composition. Contemporary population density in particular is closely connected to historical settlement patterns. We show that the effects of TFE remain sizable even after flexibly accounting for the time-varying relationship between density and social distancing.

The sluggish pandemic response among residents of high-TFE counties is mirrored by the inaction of local government. We show that policymakers in high-TFE counties are significantly less likely to enact NPIs to control the spread of the virus, including emergency declarations, stay-at-home policies, and 
mask-use mandates. While many NPIs are enacted by state governments, our results are based only on cross-county policy variation within states. Weak voluntary distancing and mask use go hand-in-hand with weak official efforts to fight COVID-19.

Both defining features of rugged individualism plausibly undermine collective action in response to public health crises. The implications of individualism are straightforward. The primacy of personal goals over group goals and the regulation of behavior by personal attitudes rather than social normstwo key dimensions of individualism-are likely to weaken voluntary social distancing and mask use. Both actions require people to internalize externalities, a key dimension of the response to infectious diseases (Althouse et al., 2010). In the case of NPIs to limit the spread of COVID-19, there are salient positive externalities. Young people have to comply with distancing even when they may perceive their risks as negligible. Individuals sometimes have to comply with strict isolation even if they are asymptomatic. Mask use is considered more protective of others than oneself. In these cases, the social returns to preventive action are much larger than the private returns.

The negative effects of individualism on collective action resonate with recent work on the pandemic. In their discussion of social and behavioral science insights on the pandemic response, Van Bavel et al. (2020) point to cultural explanations, specifically related to varying degrees of individualism. Frey et al. (2020) show that social mobility declined less in individualistic countries, while Germani et al. (2020) suggest, based on survey data from Italy, that individualistic traits hinder protective behaviors. Our findings on the link between frontier experience and social distancing within the U.S. are concurrent with those of Bian et al. (2020). Our study shows that rugged individualism, with its deep roots in American history, hinders not only voluntary responses but also public policies to fight COVID-19 spread, and that it underlies many proximate explanations for the weak pandemic response across the U.S.

The lack of civic duty is an important channel through which rugged individualism may hamper COVID-19 responses. Several recent papers show that voluntary social distancing is associated with civic culture, i.e., prosocial preferences such as reciprocity, trust, cooperation, and propensity to contribute to the public good (Barrios et al., 2020; Bartscher et al., 2020; Brodeur et al., 2020; Durante et al., 2020; Dincer and Gillanders, 2020). While individualism and civic culture are not necessarily at odds, we show that TFE (and, by implication, rugged individualism) indeed has a negative association with civic culture (proxied by voter turnout as in Barrios et al., 2020).

The other defining feature of rugged individualism, opposition to government intervention, is also likely to deter effective public health responses. Local officials with anti-statist constituencies are bound to adopt policy stances that align with the strong opposition of their voters to government intervention in its various forms, including coordinated public health efforts. In Bazzi et al. (forthcoming), we show that TFE is associated with opposition to tax redistribution and welfare spending, as well as to the Affordable Care Act (ACA), a salient policy for gauging preferences over public intervention in healthcare.

Moreover, rugged individualism has implications for understanding how partisanship has affected collective action against COVID-19. Bazzi et al. (forthcoming) show that high-TFE counties exhibit stronger (and increasing) support for the Republican Party between 2000 and 2016-a period in which Republican platforms have leaned more and more against government intervention in multiple dimensions, including health and welfare policies. In many respects, the Republican Party has come to embrace the sort of anti-statism at the heart of frontier culture. It is therefore unsurprising that Republican voters 
engage in less voluntary social distancing and less mask use, and express less support for social distancing policies (Allcott et al., 2020; Barrios and Hochberg, 2020; Milosh et al., 2020; Painter and Qiu, 2020). At the same time, Republican governors have been less prone to issue stay-at-home advisories (Baccini and Brodeur, 2020). Our results are consistent with partisan identity and beliefs being an important channel through which rugged individualism has undermined the COVID-19 response.

Another potentially important mechanism concerns distrust in science, which may partly reflect opposition to hierarchies and elites. Such attitudes are pervasive in frontier culture. In the context of COVID-19, distrust in science may reduce risk perceptions, thereby diminishing voluntary social distancing and mask use as well as more general compliance with public health advisories (see, e.g., Brzezinski et al., 2020). We assess the implications of TFE along this dimension by examining an issue in which distrust in science plays a central role: beliefs regarding climate change. We find that high-TFE counties exhibit significantly lower prevalence of beliefs that climate change is happening.

Overall, our findings illustrate a fundamental role for America's frontier culture in shaping collective action in the face of a public health emergency. Individualism weakens voluntary prevention efforts and undermines support for policy intervention. Opposition to government intervention not only reinforces individual non-compliance with NPIs but also stifles policy coordination across county lines. The social science literature has offered a range of explanations for the weak pandemic response in the U.S. We argue that many of these proximate factors have common, deep roots in the country's frontier history.

The paper proceeds as follows. Section 2 describes the data and empirical framework. Section 3 reports our main results on TFE and the evolution of social distancing, mask use, and government policies to fight COVID-19 across U.S. counties. Section 4 explores the relationship of frontier culture with different proximate explanations for collective inaction against COVID-19. Section 5 concludes.

\section{Empirical Strategy}

\subsection{Data}

Our measure of total frontier experience (TFE) comes from Bazzi et al. (forthcoming). This paper tracks frontier settlement from 1790 onward, identifying the frontier line in each year as the contour beyond which population density falls below 2 people per square mile. Counties within $100 \mathrm{~km}$ of this line and with population less than 6 people per square mile are defined as frontier counties. This historicallygrounded definition of the frontier captures both dimensions of frontier life: population sparsity and isolation from urban centers. We then construct a novel, county-level measure of TFE, which captures the number of years that each county spent on the frontier from 1790 to 1890, the end of the frontier era according to Turner (1893) and the U.S. Census Bureau. The geographic variation in TFE can be seen in Appendix Figure A.1, reproduced from Bazzi et al. (forthcoming). Our baseline analysis focuses on the 2,036 heartland counties whose entire frontier history can be observed from 1790 to 1890. Robustness checks extend to the West Coast and 20th century frontier.

We capture individual and policy responses to the pandemic with measures of social distancing, mask use, and local NPIs. Our core time-varying outcome of interest is social distancing. We consider two proxies based on mobility data. First, we use the Social Distancing Scoreboard from Unacast. This location-based data from cellphones captures the number of non-essential visits to locations outside 
the home. Second, we use Google COVID-19 Community Mobility Reports, which measure the percent change in visits to six types of destinations: workplaces, residential, grocery and pharmacy, parks, transit stations, and retail and recreation. We focus on mobility around workplaces for comparability with Unacast. ${ }^{1}$ Both data sources provide mean county-level mobility measures through August 2020 and are reported relative to pre-pandemic reference dates (i.e., a value of $60 \%$ implies that social mobility is $60 \%$ of what it was prior to the pandemic). The Unacast and Google data cover 1,378 and 1,872 counties in our sample, respectively. ${ }^{2}$

Starting in early March 2020, both the Unacast and Google data show steep and abrupt reductions in social mobility. This has been discussed at length in prior research and in the popular press. Figure 1 reveals a novel feature of this declining mobility, namely that it was more pervasive in low-TFE counties. ${ }^{3}$ Looking across the two outcomes, residents of counties in the top 25\% of TFE (26-63 years) practice roughly $10-20 \%$ less social distancing than those in the bottom $25 \%$ (TFE from 0 to 11 years). This sizable gap emerges rather suddenly in mid-March and sustains for several months thereafter. Although suggestive of a link with frontier culture, this pattern could be due to any number of factors that might be correlated with TFE and social distancing. Our empirical strategy, explained in the next section, aims at ruling out such confounders of the relationship between TFE and the pandemic response.

\section{Figure 1: TFE and Social Distancing: Basic Patterns}

(a) Non-Essential Visits

(Unacast)

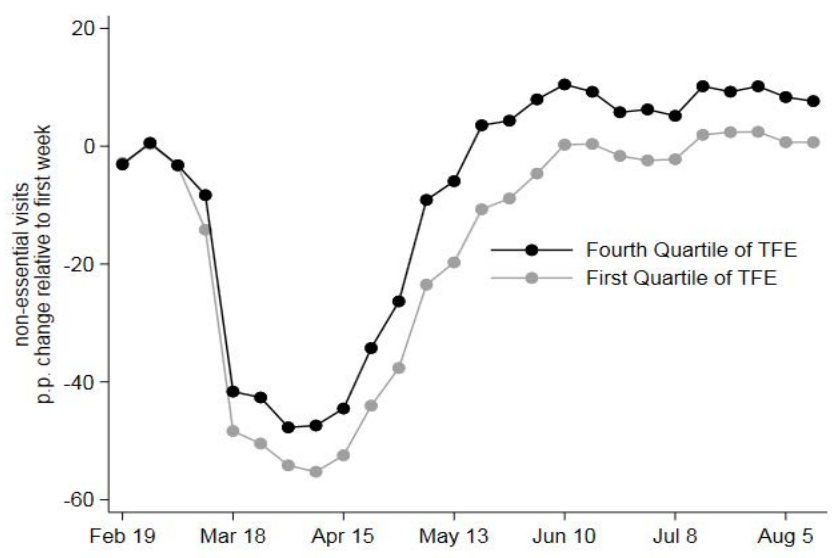

(b) Time at Workplaces (Google Community Mobility)

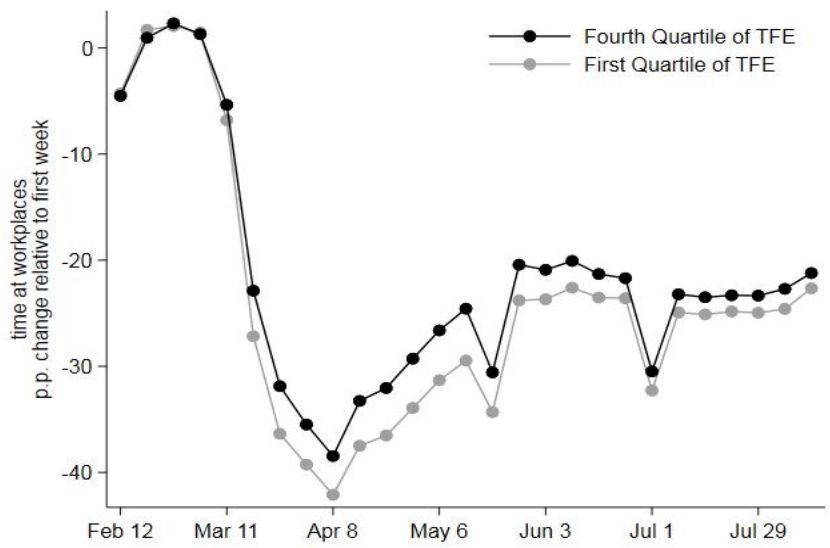

Notes: These graphs plot the evolution of social mobility since the beginning of reporting for each series in early 2020 . Each measure reflects a weekly average mobility over all days in the week relative to the first day-of-the-week in the series. The averaging explains why the series does not begin at 0 . The dark black (light gray) line corresponds to counties with total frontier experience in the top quartile (bottom quartile).

\footnotetext{
${ }^{1}$ Workplace and residential comprise the bulk of mobility, and results for time at residential areas are roughly the mirror image of the results for time at workplaces. Unacast also reports measures of distance traveled and human encounters that deliver similar insight.

${ }^{2}$ The set of counties missing from the Unacast data remains stable over time while, for a subset of counties, the Google data are available in some periods but not others. Our event study results are robust to restricting to those counties observed over the entire period and to reweighting counties according to their odds of being observed, estimated as a logit function of TFE and the baseline covariates described below.

${ }^{3}$ The Unacast and Google data exhibit differences in the extent of recovery to pre-pandemic mobility levels. The former is apparently more sensitive to seasonality than the latter. Regardless of these differences, the use of time fixed effects in our empirical strategy ensures that seasonality will not be a confounding factor in social distancing.
} 
We measure mask use with a nationally-representative survey from early July. The data are based on roughly 250,000 interviews conducted by Dynata, a survey firm, at the request of The New York Times. The survey asked respondents about the frequency of mask use ranging from never to always. It provides a cross-county snapshot of mask use several months into the pandemic, at a time when the virus had reached most of the country and mask use itself remained a hot-button cultural issue.

We measure county-level policy responses across four NPIs: emergency declarations, stay-at-home orders, business closures, and mask mandates. The first three NPIs are recorded in the National Association of Counties (NACo) County Explorer dataset, which covers over 3,070 counties across the U.S. through April 15, 2020. Our analysis focuses on the cross-section of policy enactment as this is where the primary variation lies (i.e., most counties enacted policies around the same time in March). The mask mandates come from the dataset compiled by Wright et al. (2020) and cover the entire U.S. through August 4, 2020.

\subsection{Estimating Equations}

Our empirical strategy is twofold. First, we estimate event-study specifications to identify differential trends in social distancing across high- and low-TFE counties around the national pandemic declaration on March 13th. Second, we estimate cross-sectional specifications that relate TFE to mask use and county-level NPIs. We do not relate social distancing trends to the timing of state- or county-level NPIs out of concern for endogenous policy implementation. Indeed, our analysis of NPIs suggests that TFE is associated with county-level policies to fight the pandemic.

Our event-study analysis of social distancing is based on the following equation:

$$
y_{c t}=\alpha+\sum_{j=\min }^{\max } \beta_{j} \mathrm{TFE} \times \mathbf{1}(\text { time since March } 13=j)+\theta_{c}+\gamma_{t}+\varepsilon_{c t},
$$

where $y_{c t}$ is a measure of social distancing in county $c$ at time $t$, TFE captures total frontier experience (scaled in decades), $\mathbf{1}$ (time since March $13=\mathbf{j}$ ) are indicators for the time until/after the national pandemic declaration on March 13th, $\theta_{c}$ is a county fixed effect, and $\gamma_{t}$ is a time fixed effect. Our core specification defines time at the weekly frequency, but results are robust to other horizons. We consider two extensions of equation (1): (i) state $\times$ time fixed effects $\left(\theta_{s(c) t}\right)$, and (ii) interactions of $\mathbf{1}$ (time since March $13=j$ ) with other pre-determined correlates of social distancing, an important one being population density. Together with the baseline equation (1), these specifications address potential confounding by time-invariant unobservables as well as differential trends across high- and low-TFE counties. We also estimate a simpler difference-in-difference analogue of (1) to summarize the eventstudy results.

Our cross-sectional estimating equation is given by:

$$
y_{c}=\alpha+\beta \mathrm{TFE}_{c}+\mathbf{x}_{c}^{\prime} \gamma+\theta_{s}+\varepsilon_{c}
$$

where $y_{c}$ captures mask use or county-level NPIs, $\mathbf{x}_{c}$ is a vector of predetermined county-level controls 
used in Bazzi et al. (forthcoming), ${ }^{4}$ and $\theta_{s}$ is a state fixed effect. We consider a number of extensions to equation (2), focusing on confounders explored in our prior work and new ones specific to the pandemic response. In all regressions, we cluster standard errors based on an arbitrary grid-cell approach that allows for correlated unobservables across all counties within 60 miles (Bester et al., 2011). ${ }^{5}$

\section{Rugged Individualism and Collective Inaction}

This section shows that frontier culture hindered collective action against COVID-19. Total frontier experience (TFE) — the duration of historical exposure to frontier conditions-has a negative association with social distancing, mask use, and local-government NPIs in response to COVID-19. This result is robust to many alternative explanations for the stark geographic differences in the public health response.

\subsection{Social Distancing}

Using the event-study specification (1), we find that high-TFE counties practiced considerably less social distancing after the national pandemic declaration on March 13. Figure 2 shows that around that date, TFE starts displaying positive effects on non-essential visits (panel a) and time spent at work (panel b). Panels (c) and (d) show similar patterns when we include state-by-week FE instead of simply week FE. The more demanding FE help account for variation in state-level policies at different points in time as well as differential regional evolution of public health risks (and thus of perceived needs for social distancing and other responses).

The dynamic path of point estimates in Figure 2 show a sharp break in mobility patterns immediately after the week of March 13. Each additional decade of TFE is associated with 2 percentage points (p.p.) higher likelihood of non-essential visits (panels a and c) and roughly 1.5 p.p. more time spent at work (panels $\mathrm{b}$ and $\mathrm{d}$ ). This differential response materializes quickly after March 13 and is consistent with less social distancing in high-TFE counties. These are large effects given that the within-week, cross-county standard deviation in non-essential visits is 24 p.p. and in time at work is 6 p.p.

With data beginning 2-3 weeks before March 13, we see limited evidence of pre-trends. Panels (a) and (b) suggest that residents of low-TFE counties were not increasingly less mobile prior to public awareness about the severity of COVID-19 risk. This is consistent with the abruptness of the information shock in early March. With state-by-week FE in panels (c) and (d), we see some indication of a pre-trend, though the sharp jump in coefficients after the emergency declaration remains so large that it continues to suggest a strong break from the counterfactual trend. ${ }^{6}$

\footnotetext{
${ }^{4}$ These include county area; county centroid latitude and longitude; distance to oceans,lakes and rivers from county centroid; mean county temperature and rainfall; elevation; and average potential agricultural yield.

${ }^{5}$ As in Bazzi et al. (forthcoming), inference is robust to clustering by state or by more flexible spatial structures.

${ }^{6}$ Given our objective in this analysis, the existence of pre-trends would not change our interpretation of the findings. Rather, it would suggest that residents of low-TFE counties began to engage in voluntary social distancing prior to (federal) government action to contain the virus. Any differential response prior to March 13 could be due to the same sort of mechanisms that triggered the differential response after March 13.
} 
Figure 2: TFE and Social Distancing: Event-Study Specification: County and Week FE

(a) Non-essential Visits

(Unacast)

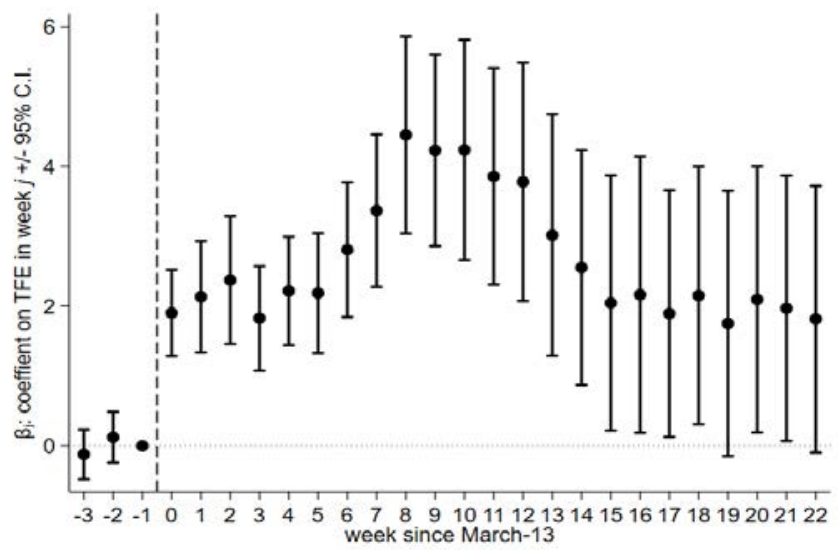

(b) Time in Workplaces

(Google Community Mobility)

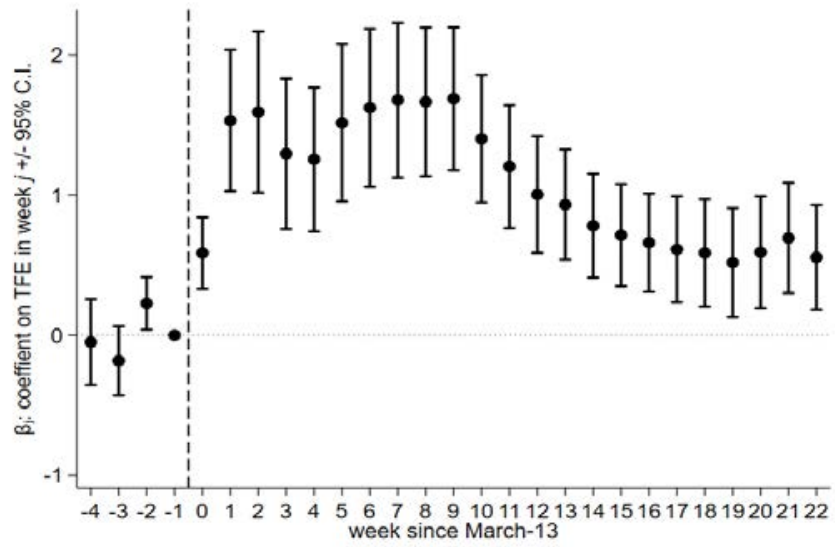

Specification: County and State-by-Week FE

(c) Non-essential Visits

(Unacast)

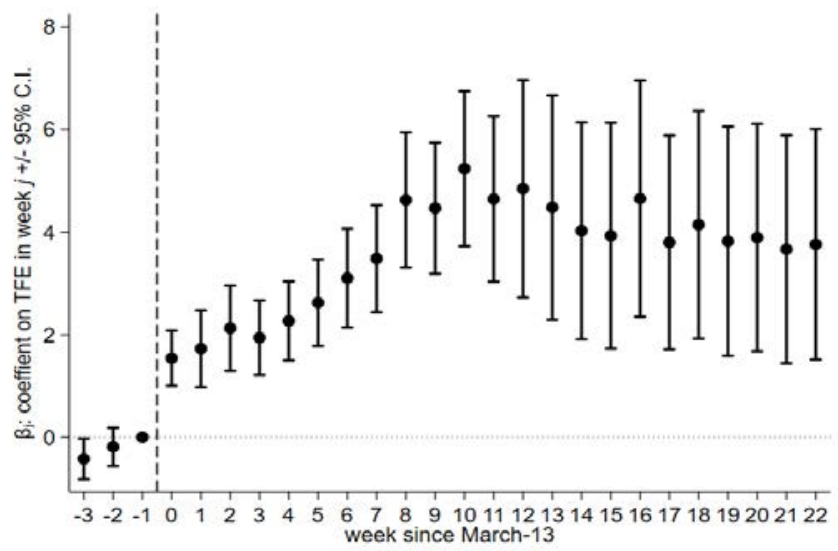

(d) Time in Workplaces

(Google Community Mobility)

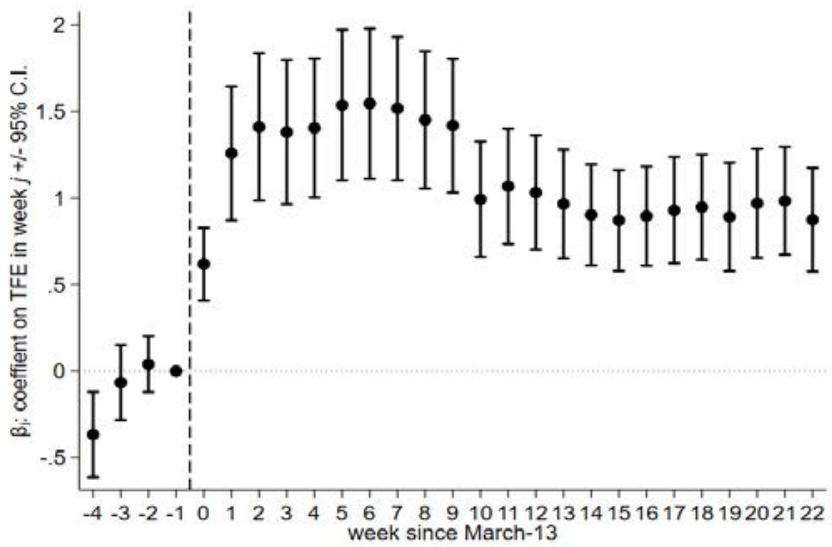

Notes: This figure reports estimates of the event-study specification in equation 1 with week and state-by-week fixed effects. All panels display point estimates by week and 95\% confidence intervals corresponding to standard errors clustered by arbitrary 60 -square-mile grid cells.

The gap in social distancing between high- and low-TFE counties becomes narrower over time in some specifications. Nearly two months after the national emergency declaration, TFE becomes significantly less correlated with social distancing in panels (a), (b) and (d). This partial convergence in behavior between high- and low-TFE places might reflect various forces, e.g., greater collective response in high-TFE places as they eventually converge in perceived health risks, or weaker collective response in low-TFE places as residents grow fatigued with protracted social distancing.

Ultimately, our event-study specification focuses on the event of the national emergency declaration as a salient information shock. In the subsequent months, there are many events with heterogeneous 
regional patterns that affect risk perceptions and calls for collective action. ${ }^{7}$ Our results in Figure 2 establish the sharp break in social distancing in high- versus low-TFE counties around the initial shock.

\subsection{Mask Use}

Besides less social distancing, high-TFE counties exhibit lower mask use. Those unwilling to voluntarily restrict activities outside the home may well be engaging in other preventative behaviors, and some may view mask use as one such substitute behavior. Although plausible, this hypothesis is rejected in Table 1. The estimates, based on the cross-sectional specification (2), suggest that greater TFE is associated with more residents reporting never, rarely, or sometimes using masks, and fewer residents reporting that they always wear a mask. Each additional decade of TFE is associated with roughly a 5-6 percent shift from regular mask use to never or rarely wearing one. These are sizable differences given that 17\% of residents in the average county report never or rarely wearing a mask outside the home while $48 \%$ report always wearing a mask.

Table 1: TFE and Mask Use

\begin{tabular}{|c|c|c|c|c|c|}
\hline \multirow[b]{3}{*}{ total frontier experience } & \multicolumn{5}{|c|}{$\begin{array}{c}\text { How often do you wear a mask in public } \\
\text { when you expect to be within six feet of another person? }\end{array}$} \\
\hline & $\begin{array}{l}\text { Never } \\
(1)\end{array}$ & $\begin{array}{l}\text { Rarely } \\
\text { (2) }\end{array}$ & $\begin{array}{l}\text { Sometimes } \\
\text { (3) }\end{array}$ & $\begin{array}{l}\text { Frequently } \\
\qquad(4)\end{array}$ & $\begin{array}{l}\text { Always } \\
\text { (5) }\end{array}$ \\
\hline & $\begin{array}{c}0.006^{* * * *} \\
(0.002)\end{array}$ & $\begin{array}{l}0.004^{* * *} \\
(0.001)\end{array}$ & $\begin{array}{c}0.009^{* * *} \\
(0.002)\end{array}$ & $\begin{array}{l}-0.000 \\
(0.002)\end{array}$ & $\begin{array}{l}-0.019^{* * *} \\
(0.003)\end{array}$ \\
\hline Number of Counties & 2,036 & 2,036 & 2,036 & 2,036 & 2,036 \\
\hline Dep. Var. Mean & 0.086 & 0.089 & 0.132 & 0.211 & 0.482 \\
\hline $\mathrm{R}^{2}$ & 0.30 & 0.27 & 0.25 & 0.16 & 0.54 \\
\hline State Fixed Effects & $\checkmark$ & $\checkmark$ & $\checkmark$ & $\checkmark$ & $\checkmark$ \\
\hline Geographic/Agroclimatic Controls & $\checkmark$ & $\checkmark$ & $\checkmark$ & $\checkmark$ & $\checkmark$ \\
\hline
\end{tabular}

Notes: This table reports estimates of equation (2) for county-level means across a series of mutually exclusive responses to a question about mask use in early July 2020. The regressions control for state fixed effects and the following predetermined controls: county area; county centroid latitude and longitude; distance to oceans,lakes and rivers from county centroid; mean county temperature and rainfall; elevation; and average potential agricultural yield. Standard errors are clustered by arbitrary 60-square-mile grid cells.

Significance levels: $*: 10 \% \quad * *: 5 \% \quad * * *: 1 \%$.

Combined with weaker social distancing, the lower mask use in high-TFE counties is consistent with individualistic opposition to collective action. Mask use, perhaps more than other risk-prevention behaviors, is seen as providing greater protection to others than to oneself. As such, the choice to wear a mask conveys concern for the well-being of those encountered in public space. The apparent greater lack of concern in high-TFE counties may stem from individualistic attitudes. It might also be due to weaker signals from local government about the importance of mask use or to distrust in the underlying science around efficacy in reducing risk.

\footnotetext{
${ }^{7}$ When controlling for time-varying, county-level COVID-19 cases and deaths, the same general pattern from Figure 2 survives. These results in Appendix Figure A.2 suggest that the dynamic relationship between TFE and social distancing is not solely driven by confounding changes in the local prevalence of infection risk.
} 


\subsection{Local Policies}

We now show that local governments in high-TFE counties are less likely to implement policies aimed to slow the spread of COVID-19. We examine the association of TFE and NPIs at the county level. Using equation (2), we estimate the effects of TFE on four types of interventions, the implementation of which varies widely across counties: emergency declarations ( $24 \%$ of sample counties by April 15 , the end of the period covered by the NACo data), stay-at-home policies (5\%), business closure policies $(1 \%)$, and mask mandates ( $40 \%$ by early August).

Table 2 reports a negative association between TFE and each of these NPIs, strongly significant for all but the business closure interventions. With state fixed effects, these estimates isolate variation in countylevel NPIs holding constant the state-level NPIs in place for those counties. While more than half of the variation in policies across counties is driven by variation across states, there are numerous counties that implement more aggressive NPIs than do their respective state governments, and still others that mandate less aggressive NPIs. The effects are sizable: each additional decade of TFE is associated with a decrease in the likelihood of NPIs on the order of $18 \%$ for emergency declarations (column 1), 50\% for stay-at-home policies (column 2), and 9\% for mask mandates (column 4).

Table 2: Local Policies

\begin{tabular}{lcccc}
\hline \hline & $\begin{array}{c}\text { Emergency } \\
\text { Declaration } \\
(1)\end{array}$ & $\begin{array}{c}\text { Stay at } \\
\text { Home } \\
(2)\end{array}$ & $\begin{array}{c}\text { Business } \\
\text { Closure } \\
(3)\end{array}$ & $\begin{array}{c}\text { Mask } \\
\text { Mandate } \\
(4)\end{array}$ \\
\cline { 2 - 5 } total frontier experience & $-0.042^{* * *}$ & $-0.025^{* * *}$ & -0.003 & $-0.036^{* * *}$ \\
& $(0.011)$ & $(0.007)$ & $(0.003)$ & $(0.008)$ \\
\hline Number of Counties & 2,036 & 2,036 & 2,036 & 2,035 \\
Dep. Var. Mean & 0.236 & 0.048 & 0.006 & 0.405 \\
$\mathrm{R}^{2}$ & 0.20 & 0.16 & 0.06 & 0.61 \\
State Fixed Effects & $\checkmark$ & $\checkmark$ & $\checkmark$ & $\checkmark$ \\
Geographic/Agroclimatic Controls & $\checkmark$ & $\checkmark$ & $\checkmark$ & $\checkmark$ \\
\hline \hline
\end{tabular}

Notes: This table reports linear probability estimates of equation (2) for the incidence of four county-level NPIs listed at the top of each column. The regressions control for state fixed effects and the following predetermined controls: county area; county centroid latitude and longitude; distance to oceans,lakes and rivers from county centroid; mean county temperature and rainfall; elevation; and average potential agricultural yield. Standard errors are clustered by arbitrary 60-square-mile grid cells.

Significance levels: $*: 10 \% \quad * *: 5 \% \quad * * *: 1 \%$.

The results thus far suggest a strong link between frontier culture and the pandemic response. Residents of high-TFE counties are more likely to eschew social distancing and mask use, and their representatives are more likely to avoid public intervention aimed at changing individual behavior. These two sides of collective inaction are, of course, connected. Lack of distancing and mask-wearing may reflect weak or absent policies to nudge and coordinate such preventative behaviors. At the same time, the policy choices of local governments tend to reflect the preferences of their constituencies. While preferences and policies both shape behavior, we do not attempt to disentangle their relative importance in this paper. 


\subsection{Robustness Checks}

We consider several alternative explanations for the relationship between TFE and the response to COVID-19. First, the results in Figure 2 cannot be fully explained by other county-specific determinants of COVID-19 risk and social distancing. We show this in Appendix Figure A.3 by separately interacting several county-level covariates with time-to-event, mirroring the interaction with county-level TFE. The potential confounders include population density, temperature, income, education, and racial composition, each of which has featured prominently in prior work exploring the pandemic risk and response (see, e.g., Ahmadi et al., 2020; Brown and Ravallion, 2020; Chiou and Tucker, 2020; Coven and Gupta, 2020; Sajadi et al., 2020). While some, like population density and temperature, remain the subject of debate about the precise risk mechanism, the mere perception of risk could shape prevention behavior. Some of these measures are themselves potential outcomes of TFE, which can make interpretation difficult. Nevertheless, the fact that the event-study results are robust to these additional controls suggests that they are unlikely to be important confounders. Appendix Table A.4 provides similar evidence of robustness using a simpler difference-in-difference specification with county FE that merely interacts TFE and the other covariates with an indicator for weeks after March 13.

The cross-sectional estimates for mask use and local policies are also generally robust to adding the same potential confounders as controls (see Appendix Tables A.2 and A.3). Together, these results suggest that TFE captures variation in the pandemic response that is not related to leading demographic and environmental factors associated with COVID-19 risk.

Disentangling Population Density. It is worth emphasizing that our findings cannot be explained by differences in population density across high- and low-TFE counties. Contemporary population density is strongly decreasing in TFE, and in some of the the robustness checks described above, a linear control for density reduced the effects of TFE on social distancing, mask use, and NPIs. Appendix Tables A.5 and A.6 show that the effects of TFE remain sizable with even more flexible controls for density. The matching-type exercise in column 4 is an extremely demanding specification: for each county, we find the county within the same state with the most similar population density and create matched pairs, define a dummy for each pair, and then add these as fixed effects (interacted with the post-March 13 indicator in the social distancing regressions). Columns 5 and 6 split the sample into counties above versus below the 90th percentile of population density, the former being urban areas. The effects of TFE generally survive across these specifications, which suggests that frontier culture and its implications for collective action cut across the density divide.

Regional Variation and the 20th Century Frontier. Appendix Tables A.7 and A.8 explore regional heterogeneity in the effects of TFE on social distancing, mask use, and NPIs. First, we add 105 West Coast frontier counties that were settled starting in the mid-19th century (column 1). We then split the sample by Census region: the Midwest (column 2), the South (column 3), and the West (column 4). The estimates are noisier for the latter given the smaller number of counties. In subsequent columns 5-8, we extend the frontier time-frame, thereby including counties that experienced frontier conditions beyond 1890. Overall, the findings remain largely unchanged across all these checks. 


\section{Frontier Culture and Proximate Causes of Inaction}

This section explores why frontier culture undermined the pandemic response. We show that TFE underlies several leading explanations for opposition to social distancing, mask use, and NPIs.

In Table 3, we examine the association of TFE with civic culture, anti-statist partisanship, and trust in science. Each of these has been linked to variation in the public health response to COVID-19. We argue here that frontier culture underpins these findings. There are of course numerous other correlates of the individual and policy response to COVID-19. Our goal in this section is not to provide an exhaustive account of the role of TFE in understanding all of these associations documented in prior work. Rather, we aim to demonstrate that frontier culture may be a unifying explanation across a set of important factors underlying the public health response to the pandemic.

Many have argued that civic culture helped to promote voluntary social distancing. The strand of individualism cultivated on the American frontier tends to go against civic culture. Historically, frontier settlers had to rely on themselves for protection and prevention, and to improve their living conditions. While returns to cooperation may have been high, maintaining reciprocity would have been challenging given the high population mobility on the frontier. The "rugged" aspect of frontier culture, and the prevalence of violence in frontier societies, plausibly made this type of individualism particularly inimical to civic culture.

We explore the association of TFE with a common proxy measure of civic culture: voter turnout. Barrios et al. (2020) show that this measure is negatively correlated with social distancing. We share their interpretation: weaker civic culture implies lower disposition to internalize externalizes and take costly actions that contribute to the common good. Table 3 reveals a negative association between TFE and average voter turnout across the last five presidential elections (column 1). ${ }^{8}$ Each additional decade of TFE is associated with nearly 0.5 p.p. lower turnout relative to a mean of $58 \%$ (std. dev. of $8.7 \%$ ).

Residents of high-TFE counties not only display lower civic capital but also greater anti-statist partisanship, which can be an obstacle to public health during a pandemic. Bazzi et al. (forthcoming) show that high-TFE counties exhibit stronger and increasing support for the Republican Party between 2000 and 2016 (see column 2 of Table 3 below for the estimated effect of TFE in 2016). During this period, the Republican platform has increasingly aligned with the principles of rugged individualism. In Bazzi et al. (forthcoming), we showed that TFE is associated with opposition to tax redistribution, welfare spending, and other forms of government intervention, including the Affordable Care Act (ACA). Opposition to the ACA, a program for state-led provision of affordable health care, reflects, in part, opposition to seeing health as a right or as a public good. This ideology is likely to hamper the response to an infectious disease epidemic like COVID-19, which requires individuals and government to address externalities through collective action. Opposition to tax redistribution and welfare programs may also be an obstacle, since stay-at-home policies require support for individuals whose livelihoods are threatened.

The anti-statist element of rugged individualism and its partisan expression in the Republican Party may have limited the policy response to the pandemic while also undermining individual willingness to engage in costly collective action around social distancing and mask use. Others have shown that Republican voters are less likely to engage in social distancing (Barrios and Hochberg, 2020; Gadarian

\footnotetext{
${ }^{8}$ The county-level voting outcomes in this section are based on data from Leip's Atlas of U.S. Presidential Elections.
} 
et al., 2020; Painter and Qiu, 2020) and mask use (Milosh et al., 2020), and that Republican leaders are more likely to downplay the risks of COVID-19 (Allcott et al., 2020) and less likely to issue NPIs (Baccini and Brodeur, 2020). We argue that the frontier culture of rugged individualism lies at the heart of these partisan responses to the pandemic.

Another way in which frontier culture has shaped the pandemic response is through distrust in science and experts more generally. Frontier culture, insofar as it leads to opposition to all kinds of hierarchies, may be associated with distrust in science. Historically, the frontier was characterized by novel and uncertain conditions where traditions and rules of thumb acquired elsewhere were often illsuited. This created an advantage for individualism, a trait that is associated with resourcefulness, nonconformism, and inventiveness (Raz, 2020; Shannon, 1977). While the context changed, there may be an enduring frontier cultural opposition toward established norms and hierarchies, including those based on science and education.

Table 3: Civic culture, anti-statist partisanship, and distrust in science

\begin{tabular}{|c|c|c|c|}
\hline & $\begin{array}{l}\text { Civic Capital } \\
\text { (Avg. Turnout } \\
\text { 2000-16) } \\
(1) \\
\end{array}$ & $\begin{array}{c}\text { Republican } \\
\text { Vote Share } \\
2016 \\
(2) \\
\end{array}$ & $\begin{array}{c}\text { Don't Think } \\
\text { Global Warming } \\
\text { Is Happening } \\
\text { (3) }\end{array}$ \\
\hline total frontier experience & $\begin{array}{c}-0.438^{* *} \\
(0.176)\end{array}$ & $\begin{array}{c}3.154^{* * *} \\
(0.416)\end{array}$ & $\begin{array}{c}0.919 * * * \\
(0.130)\end{array}$ \\
\hline Number of Counties & 2,036 & 2,036 & 2,036 \\
\hline Dep. Var. Mean & 57.865 & 65.420 & 21.751 \\
\hline $\mathrm{R}^{2}$ & 0.53 & 0.32 & 0.35 \\
\hline State Fixed Effects & $\checkmark$ & $\checkmark$ & $\checkmark$ \\
\hline Geographic/Agroclimatic Controls & $\checkmark$ & $\checkmark$ & $\checkmark$ \\
\hline
\end{tabular}

Notes: This table reports estimates of equation (2) for the outcomes listed at the top of each column. The regressions control for state fixed effects and the following predetermined controls: county area; county centroid latitude and longitude; distance to oceans,lakes and rivers from county centroid; mean county temperature and rainfall; elevation; and average potential agricultural yield. Standard errors are clustered by arbitrary 60-square-mile grid cells.

Significance levels: $*: 10 \% \quad * *: 5 \% \quad * * *: 1 \%$.

To assess this possibility, we examine a salient topic on which distrust in science plays a key role: beliefs regarding climate change. Brzezinski et al. (2020) show that those who believe in the severity of global warming are more likely to engage in social distancing and to comply with government-mandated public health advisories. We show in Table 3 that frontier culture is associated with disbelief in climate change. Each additional decade of TFE is associated with a 1 p.p. increase in the share of residents that do not believe global warming is happening, according to survey data collected by the Yale Program on Climate Change Communication (Howe et al., 2015). This is a meaningful effect given that $22 \%$ of residents in the mean county hold such disbelief. This result suggests that distrust in science is one important way in which frontier culture undermines public health campaigns. 


\section{Conclusion}

American rugged individualism - the combination of individualism and opposition to government intervention-has undermined collective action against the COVID-19 pandemic. We provide the first empirical evidence that frontier culture is central to understanding the weak public health response. Counties with longer historical frontier experience exhibit less mask use, less social distancing, and fewer NPIs. These counties also exhibit weaker civic capital, stronger anti-statist partisanship, and greater distrust in science, which are, among others, important proximate determinants of the country's weak public health response. We argue that America's frontier culture of rugged individualism is at the heart of its flawed response to the COVID-19 pandemic. An effective response requires strong collective action, the likes of which has eluded many areas of the country with a deep historical connection to the frontier.

The fragmented response to COVID-19 that we identify may have broader aggregate implications. As high- and low-TFE counties adopt different approaches to the pandemic, this makes it more difficult to blunt the spread of infection. Prevention success in one county will be offset and even undone as individuals come into contact with those from other counties with weaker responses. Ultimately, America's federal system of government-itself intertwined with the country's frontier history-makes it difficult to avoid such spillovers.

Individualistic responses to collective risk can pose grave public health consequences, especially in a context like the U.S. where institutions freely permit such a response. The U.S. legal system is predicated on the protection of individual liberties and decentralized governance. In his book, The Pox of Liberty: How the Constitution Left Americans Rich, Free, and Prone to Infection, Troesken (2015) describes how the institutional emphasis on individual liberties undermined America's historical response to smallpox by making vaccine (inoculation) avoidance possible. While America is considerably richer and its healthcare more advanced today, the institutional context is similar, and rugged individualism seems more entrenched than ever. Looking forward, it will be important to examine whether frontier culture hinders an effective COVID-19 immunization campaign if and when a vaccine becomes available. 


\section{References}

Ahmadi, Mohsen, Abbas Sharifi, Shadi Dorosti, Saeid Jafarzadeh Ghoushchi, and Negar Ghanbari, "Investigation of effective climatology parameters on COVID-19 outbreak in Iran," Science of the Total Environment, 2020, p. 138705.

Allcott, Hunt, Levi Boxell, Jacob Conway, Matthew Gentzkow, Michael Thaler, and David Y Yang, "Polarization and public health: Partisan differences in social distancing during the Coronavirus pandemic," NBER Working Paper 26946, 2020.

Althouse, Benjamin M., Theodore C. Bergstrom, and Carl T. Bergstrom, "A public choice framework for controlling transmissible and evolving diseases," Proceedings of the National Academy of Sciences, 2010, 107 (suppl 1), 1696-1701.

Baccini, Leonardo and Abel Brodeur, "Explaining Governors' Response to the COVID-19 Pandemic in the United States," IZA Discussion Paper No. 13137, 2020.

Barrios, John $\mathbf{M}$ and Yael Hochberg, "Risk perception through the lens of politics in the time of the covid-19 pandemic," NBER Working Paper 27008, 2020.

_ , Efraim Benmelech, Yael V Hochberg, Paola Sapienza, and Luigi Zingales, "Civic capital and social distancing during the covid-19 pandemic," NBER Working Paper 27320, 2020.

Bartscher, Alina K, Sebastian Seitz, Michaela Slotwinski, Sebastian Siegloch, and Nils Wehrhöfer, "Social capital and the spread of Covid-19: Insights from European countries," CESifo Working Paper Series 8346, 2020.

Bavel, Jay J. Van, Katherine Baicker, Paulo S Boggio, Valerio Capraro, Aleksandra Cichocka, Mina Cikara, Molly J Crockett, Alia J Crum, Karen M Douglas, James N Druckman et al., "Using social and behavioural science to support COVID-19 pandemic response," Nature Human Behaviour, 2020, pp. 1-12.

Bazzi, Samuel, Martin Fiszbein, and Mesay Gebresilasse, "Frontier Culture: The Roots and Persistence of 'Rugged Individualism' in the United States," Econometrica, forthcoming.

Bester, C Alan, Timothy G Conley, and Christian B Hansen, "Inference with dependent data using cluster covariance estimators," Journal of Econometrics, 2011, 165 (2), 137-151.

Bian, Bo, Jingjing Li, Ting $\mathbf{X u}$, and Natasha Foutz, "Individualism During Crises: Big Data Analytics of Collective Actions amid COVID-19," SSRN Working Paper 3620364, 2020.

Brodeur, Abel, Idaliya Grigoryeva, and Lamis Kattan, "Stay-At-Home Orders, Social Distancing and Trust," IZA Discussion Paper No. 13234, 2020.

Brown, Caitlin S and Martin Ravallion, "Inequality and the Coronavirus: Socioeconomic Covariates of Behavioral Responses and Viral Outcomes Across US Counties," NBER Working Paper 27549, 2020.

Brzezinski, Adam, Valentin Kecht, David Van Dijcke, and Austin L Wright, "Belief in science influences physical distancing in response to covid-19 lockdown policies," University of Chicago, Becker Friedman Institute for Economics Working Paper, 2020, (2020-56).

Chiou, Lesley and Catherine Tucker, "Social distancing, internet access and inequality," NBER Working Paper 26982, 2020.

Coven, Joshua and Arpit Gupta, "Disparities in mobility responses to covid-19," NYU Stern Working 
Paper, 2020.

Dincer, Oguzhan C. and Robert Gillanders, "Shelter in Place? Depends on the Place: Corruption and Social Distancing in American States," Depends on the Place: Corruption and Social Distancing in American States (May 28, 2020), 2020.

Durante, Ruben, Lugi Guiso, and Giorgio Gulino, "Civic capital and social distancing: evidence from Italians' response to COVID-19," SSRN 3611606, 2020.

Frey, Carl Benedikt, Chinchih Chen, and Giorgio Presidente, "Democracy, Culture, and Contagion: Political Regimes and Countries Responsiveness to Covid-19," Covid Economics, 2020, 18, 1-20.

Gadarian, Shana Kushner, Sara Wallace Goodman, and Thomas B. Pepinsky, "Partisanship, health behavior, and policy attitudes in the early stages of the COVID-19 pandemic," Working Paper, 2020.

Germani, Alessandro, Livia Buratta, Elisa Delvecchio, and Claudia Mazzeschi, "Emerging Adults and COVID-19: The Role of Individualism-Collectivism on Perceived Risks and Psychological Maladjustment," International Journal of Environmental Research and Public Health, 2020, 17 (10), 3497.

Howe, Peter D, Matto Mildenberger, Jennifer R Marlon, and Anthony Leiserowitz, "Geographic variation in opinions on climate change at state and local scales in the USA," Nature Climate Change, 2015, 5 (6), 596-603.

Manson, Steven, Jonathan Schroeder, David Van Riper, and Steven Ruggles, "IPUMS National Historical Geographic Information System: Version 14.0 [Database].," Minneapolis, MN: IPUMS. 2019.

Milosh, Maria, Marcus Painter, David Van Dijcke, and Austin L. Wright, "Unmasking Partisanship: How Polarization Influences Public Responses to Collective Risk," University of Chicago, Becker Friedman Institute for Economics Working Paper, 2020, (2020-102).

Painter, Marcus and Tian Qiu, "Political beliefs affect compliance with covid-19 social distancing orders," Available at SSRN 3569098, 2020.

Raz, Itzchak Tzachi, "Learning is Caring: Soil Heterogeneity, Social Learning and the Formation of Close-knit Communities," Unpublished Manuscript, 2020.

Sajadi, Mohammad M, Parham Habibzadeh, Augustin Vintzileos, Shervin Shokouhi, Fernando Miralles-Wilhelm, and Anthony Amoroso, "Temperature and latitude analysis to predict potential spread and seasonality for COVID-19," SSRN 3550308, 2020.

Shannon, Fred A., The Farmer's Last Frontier: Agriculture, 1860-1897, Vol. 5, ME Sharpe, 1977.

Troesken, Werner, The pox of liberty: how the constitution left Americans rich, free, and prone to infection, University of Chicago Press, 2015.

Turner, Frederick Jackson, "The Significance of the Frontier in American History," Proceedings of the State Historical Society of Wisconsin, 1893.

Wright, Austin L., Geet Chawla, Luke Chen, and Anthony Farmer, "Tracking Mask Mandates During the Covid-19 Pandemic," University of Chicago, Becker Friedman Institute for Economics Working Paper $104,2020$. 


\section{Appendix}

Figure A.1: Total Frontier Experience (1790 to 1890)

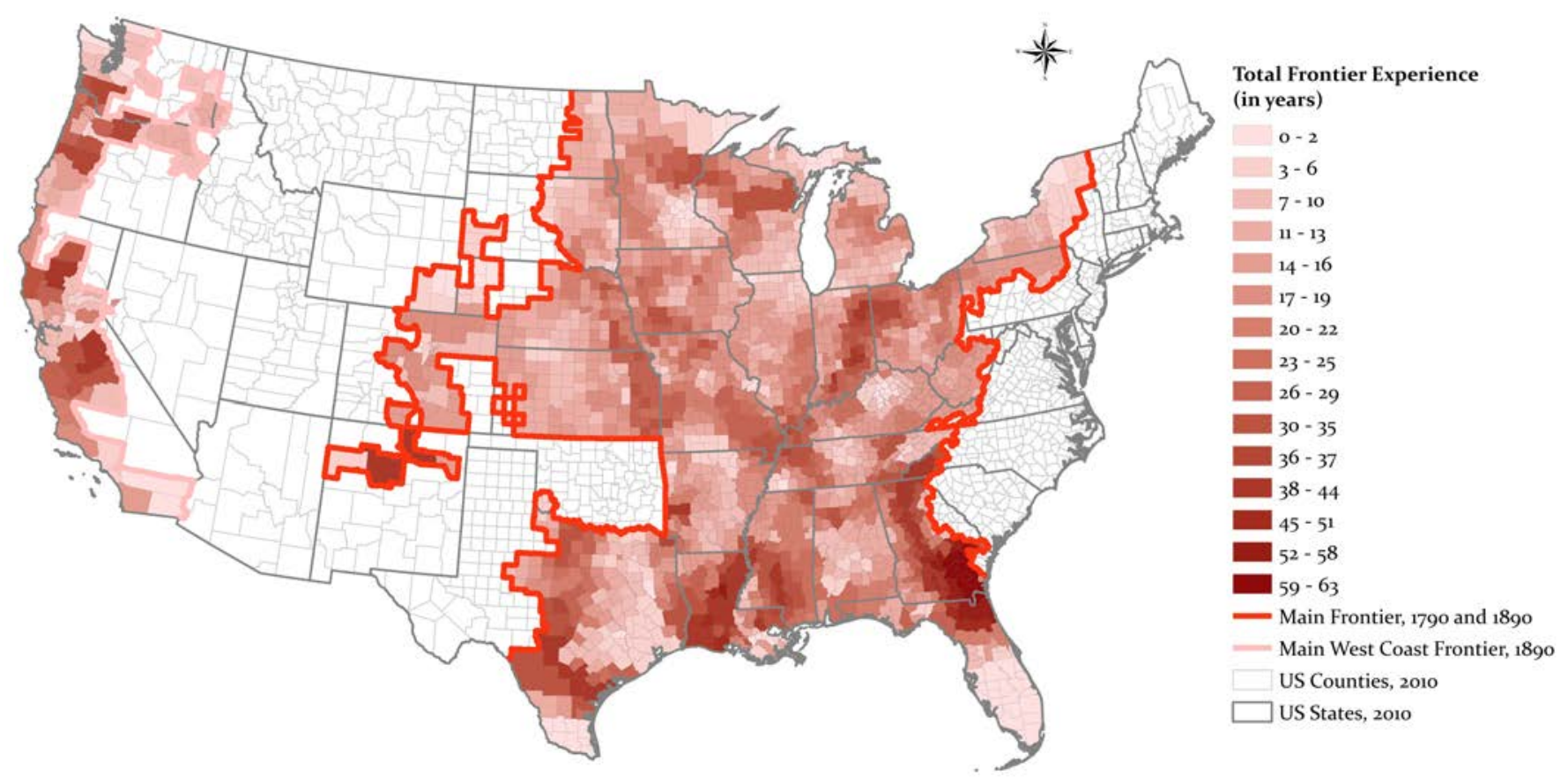

Notes: This figure is reproduced from Bazzi et al. (forthcoming). It is based on county-level data from NHGIS (Manson et al., 2019). Total frontier experience is the total number of years the county was within $100 \mathrm{~km}$ of the frontier line and its population density was below 6 people per square mile, between 1790-1890. The white areas to the east of the 1790 main frontier line are counties for which we do not know frontier history given the lack of Population Census data before 1790 . The white areas to the west are beyond the 1890 frontier line. 
Figure A.2: TFE and Social Distancing controlling for Lagged Per Capita Cases and Deaths Specification: County and Week FE

(a) Non-essential Visits

(Unacast)

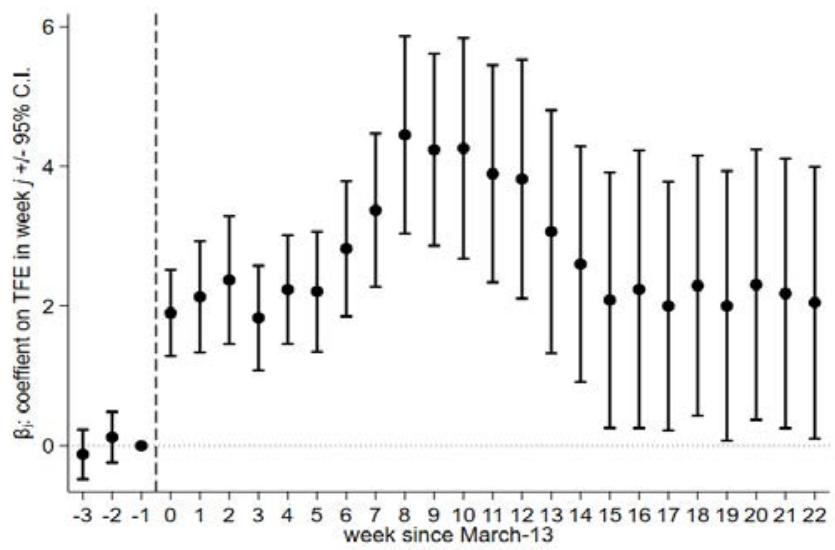

(b) Time in Workplaces

(Google Community Mobility)

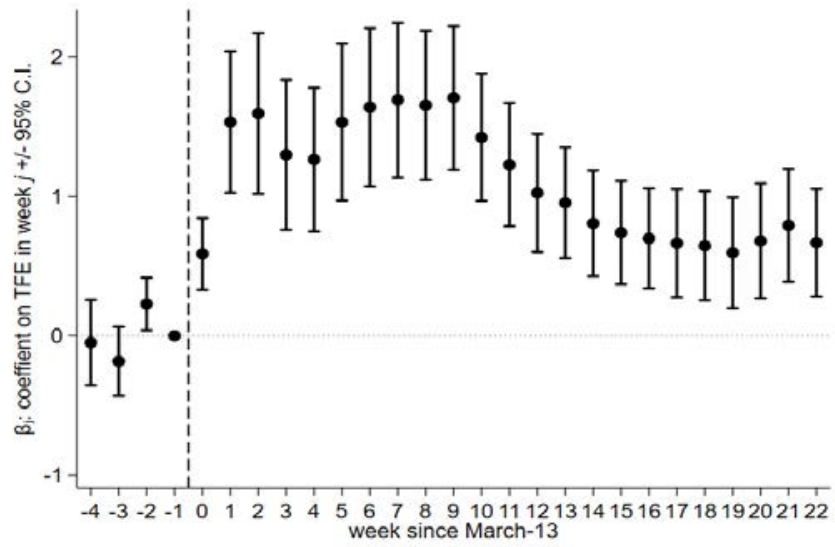

Specification: County and State-by-Week FE

(c) Non-essential Visits

(Unacast)

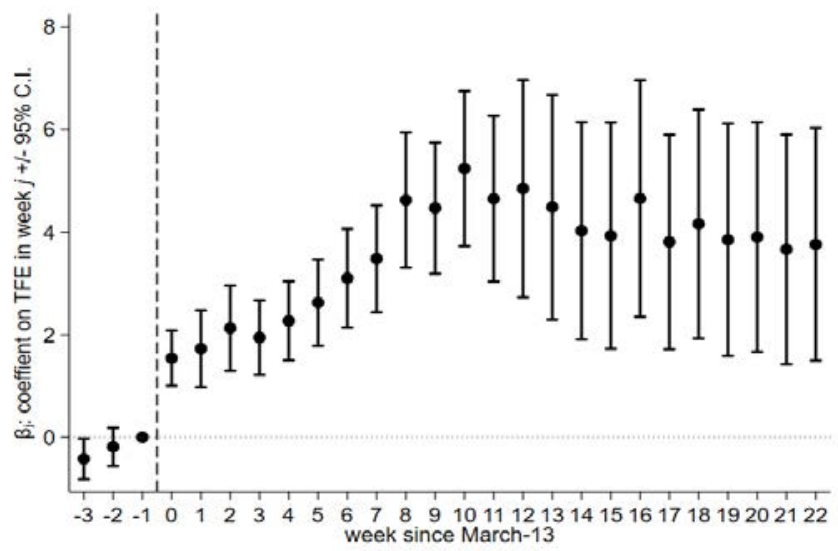

(d) Time in Workplaces

(Google Community Mobility)

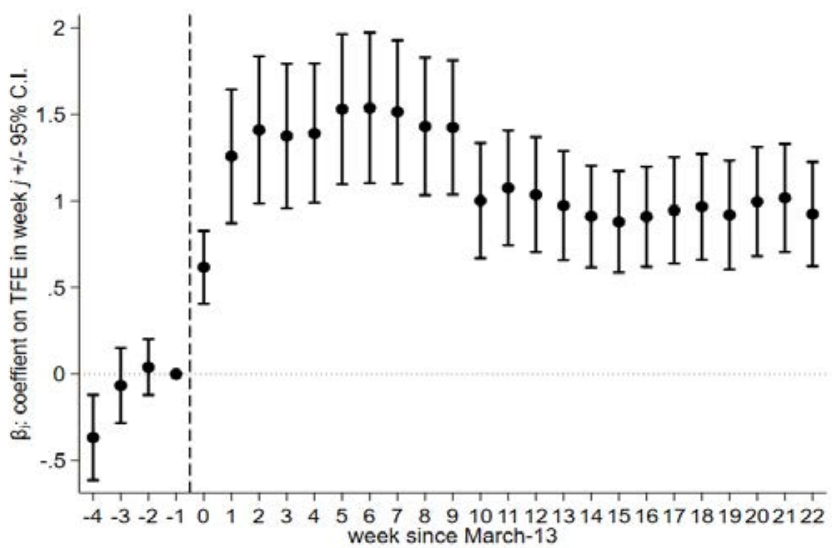

Notes: This figure displays estimation results for our event-study specification in equation 1 for two different outcomes, with and without state-by-week fixed effects. All panels display point estimates by week and $95 \%$ confidence intervals corresponding to standard errors clustered by arbitrary 60-square-mile grid-cells. 
Figure A.3: Robustness Check: TFE and Social Distancing Specification: County and Week FE

(a) Non-essential Visits

(Unacast)

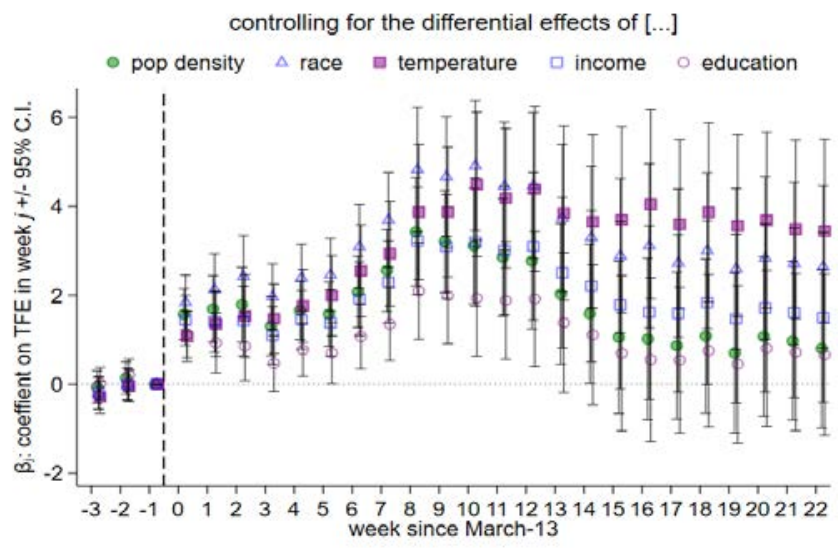

(b) Time in Workplaces

(Google Community Mobility)

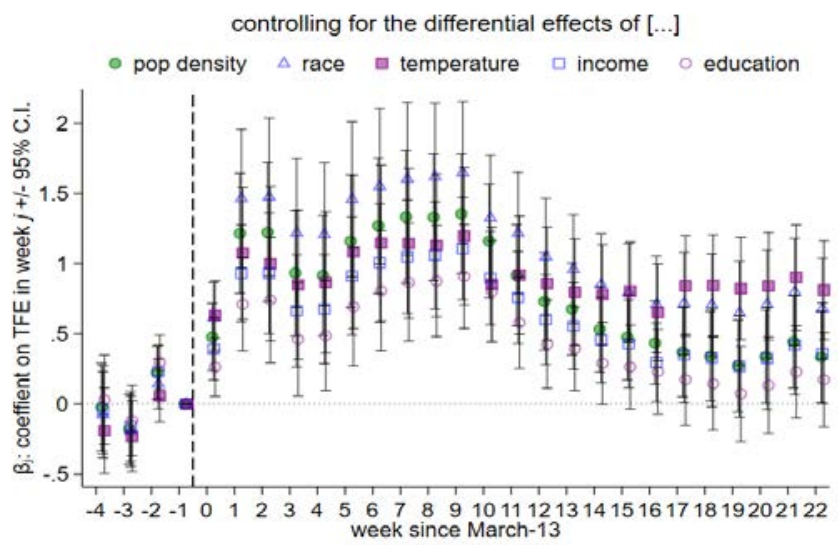

\section{Specification: County and State-by-Week FE}

(a) Non-essential Visits

(Unacast)

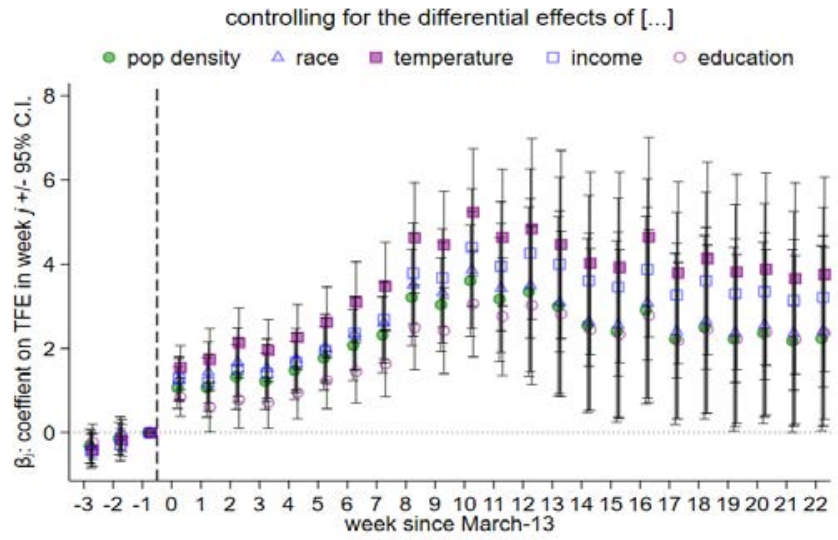

(b) Time in Workplaces

(Google Community Mobility)

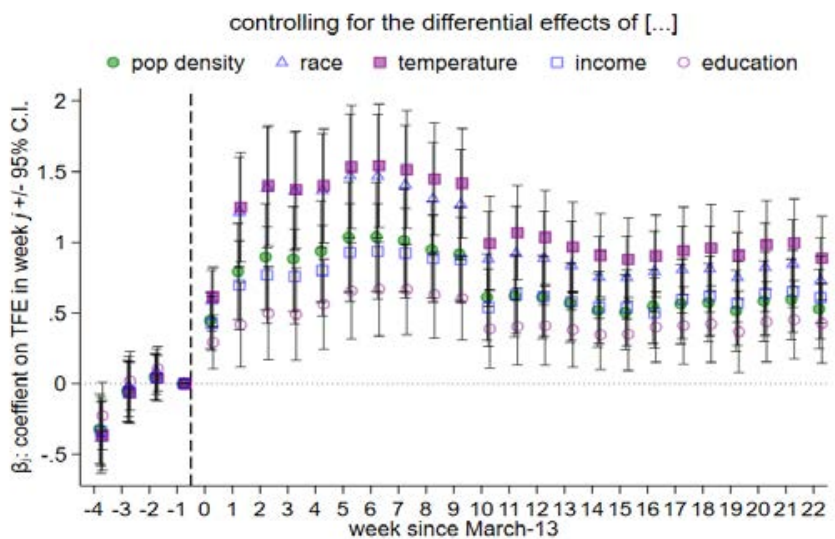

Notes: This figure displays estimation results for our event-study specification in equation 1 for two different outcomes and controlling for, separately, county level population density, race (share of white), mean temperature, median income or education (share with post-secondary educatiob) interacted with time-to-event dummies. The first panel icnludes county and week fixed effects while the second panel uses county and state-by-week fixed effects. All panels display point estimates by week and $95 \%$ confidence intervals corresponding to standard errors clustered by arbitrary 60 -square-mile grid-cells. 
Table A.1: Robustness Checks: TFE and Social Distancing

\begin{tabular}{|c|c|c|c|c|c|c|c|}
\hline & $(1)$ & $(2)$ & $(3)$ & $(4)$ & $(5)$ & $\overline{(6)}$ & $\overline{(7)}$ \\
\hline & \multicolumn{7}{|c|}{ (a) Non-essential Visits (Unacast) } \\
\hline TFE $\times$ post-March-13 & $\begin{array}{c}2.645^{* * *} \\
(0.619)\end{array}$ & $\begin{array}{c}1.746^{* * *} \\
(0.529)\end{array}$ & $\begin{array}{l}3.238^{* * *} \\
(0.579)\end{array}$ & $\begin{array}{c}3.255^{* * *} \\
(0.645)\end{array}$ & $\begin{array}{c}2.057^{* * *} \\
(0.593)\end{array}$ & $\begin{array}{l}1.003^{*} \\
(0.531)\end{array}$ & $\begin{array}{c}1.731^{* * *} \\
(0.544)\end{array}$ \\
\hline pop. density $\times$ post-March-13 & & $\begin{array}{l}-0.018^{* * *} \\
(0.002)\end{array}$ & & & & & $\begin{array}{c}-0.007^{* * *} \\
(0.001)\end{array}$ \\
\hline share white $\times$ post-March-13 & & & $\begin{array}{c}0.483^{* * *} \\
(0.054)\end{array}$ & & & & $\begin{array}{c}0.282^{* * *} \\
(0.058)\end{array}$ \\
\hline temperature $\times$ post-March-13 & & & & $\begin{array}{c}-0.685^{* * *} \\
(0.218)\end{array}$ & & & $\begin{array}{c}-0.469^{* *} \\
(0.237)\end{array}$ \\
\hline median income $\times$ post-March-13 & & & & & $\begin{array}{c}-0.000^{* * *} \\
(0.000)\end{array}$ & & $\begin{array}{c}0.000^{* * *} \\
(0.000)\end{array}$ \\
\hline share post-sec. educ $\times$ post-March-13 & & & & & & $\begin{array}{c}-1.027^{* * *} \\
(0.061)\end{array}$ & $\begin{array}{c}-1.097^{* * *} \\
(0.106)\end{array}$ \\
\hline Number of County-Weeks & 35,828 & 35,828 & 35,828 & 35,750 & 35,828 & 35,828 & 35,750 \\
\hline \multirow[t]{2}{*}{ Dep. Var. Mean } & -10.8 & -10.8 & -10.8 & -10.8 & -10.8 & -10.8 & -10.8 \\
\hline & \multicolumn{7}{|c|}{ (b) Time at Workplaces (Google Community Mobility) } \\
\hline TFE $\times$ post-March-13 & $\begin{array}{c}1.075^{* * *} \\
(0.192)\end{array}$ & $\begin{array}{l}0.787^{* * *} \\
(0.151)\end{array}$ & $\begin{array}{l}1.119 * * * \\
(0.191)\end{array}$ & $\begin{array}{l}0.996^{* * *} \\
(0.189)\end{array}$ & $\begin{array}{c}0.635^{* * *} \\
(0.131)\end{array}$ & $\begin{array}{c}0.413^{* * *} \\
(0.129)\end{array}$ & $\begin{array}{c}0.390^{* * *} \\
(0.121)\end{array}$ \\
\hline pop. density $\times$ post-March-13 & & $\begin{array}{c}-0.007^{* * *} \\
(0.001)\end{array}$ & & & & & $\begin{array}{c}-0.003^{* * *} \\
(0.001)\end{array}$ \\
\hline share white $\times$ post-March-13 & & & $\begin{array}{l}0.028^{* *} \\
(0.011)\end{array}$ & & & & $\begin{array}{c}0.007 \\
(0.012)\end{array}$ \\
\hline temperature $\times$ post-March-13 & & & & $\begin{array}{c}0.070 \\
(0.053)\end{array}$ & & & $\begin{array}{l}-0.045 \\
(0.041)\end{array}$ \\
\hline median income $\times$ post-March-13 & & & & & $\begin{array}{l}-0.000^{* * *} \\
(0.000)\end{array}$ & & $\begin{array}{l}-0.000^{* * *} \\
(0.000)\end{array}$ \\
\hline share post-sec. educ $\times$ post-March-13 & & & & & & $\begin{array}{c}-0.420^{* * *} \\
(0.019)\end{array}$ & $\begin{array}{c}-0.306^{* * *} \\
(0.026)\end{array}$ \\
\hline Number of County-Weeks & 49,938 & 49,938 & 49,938 & 49,857 & 49,938 & 49,938 & 49,857 \\
\hline Dep. Var. Mean & -22.4 & -22.4 & -22.4 & -22.4 & -22.4 & -22.4 & -22.4 \\
\hline County Fixed Effects & $\checkmark$ & $\checkmark$ & $\checkmark$ & $\checkmark$ & $\checkmark$ & $\checkmark$ & $\checkmark$ \\
\hline Time Fixed Effects & $\checkmark$ & $\checkmark$ & $\checkmark$ & $\checkmark$ & $\checkmark$ & $\checkmark$ & $\checkmark$ \\
\hline
\end{tabular}

Notes: This table reports estimates of the simpler difference-in-difference analogue of specification in equation (1) for two different outcomes and accounting for potential confounders interacted with an indicator for post-March-13. Standard errors are clustered by arbitrary 60 -square-mile grid cells.

Significance levels: $*: 10 \% \quad * *: 5 \% \quad * * *: 1 \%$. 
Table A.2: Robustness Checks: TFE and Mask Use

\begin{tabular}{|c|c|c|c|c|c|c|c|}
\hline & \multicolumn{7}{|c|}{$\begin{array}{c}\text { Share who always wear a mask in public } \\
\text { when they expect to be within six feet of another person }\end{array}$} \\
\hline & (1) & (2) & (3) & $(4)$ & (5) & (6) & (7) \\
\hline total frontier experience & $\begin{array}{c}-0.019^{* * *} \\
(0.003)\end{array}$ & $\begin{array}{c}-0.014^{* * *} \\
(0.003)\end{array}$ & $\begin{array}{c}-0.016^{* * *} \\
(0.003)\end{array}$ & $\begin{array}{c}-0.019^{* * *} \\
(0.003)\end{array}$ & $\begin{array}{c}-0.015^{* * *} \\
(0.003)\end{array}$ & $\begin{array}{c}-0.012^{* * *} \\
(0.003)\end{array}$ & $\begin{array}{c}-0.008^{* * *} \\
(0.003)\end{array}$ \\
\hline pop. density & & $\begin{array}{c}0.000^{* * *} \\
(0.000)\end{array}$ & & & & & $\begin{array}{c}0.000^{* * *} \\
(0.000)\end{array}$ \\
\hline share white & & & $\begin{array}{c}-0.002^{* * *} \\
(0.000)\end{array}$ & & & & $\begin{array}{c}-0.002^{* * *} \\
(0.000)\end{array}$ \\
\hline temperature & & & & $\begin{array}{l}-0.001 \\
(0.009)\end{array}$ & & & $\begin{array}{l}-0.008 \\
(0.007)\end{array}$ \\
\hline median income & & & & & $\begin{array}{c}0.000^{* * *} \\
(0.000)\end{array}$ & & $\begin{array}{c}0.000^{* * *} \\
(0.000)\end{array}$ \\
\hline share post-sec. educ & & & & & & $\begin{array}{c}0.005^{* * *} \\
(0.000)\end{array}$ & $\begin{array}{c}0.002^{* * *} \\
(0.000)\end{array}$ \\
\hline Number of Counties & 2,036 & 2,036 & 2,036 & 2,036 & 2,036 & 2,036 & 2,036 \\
\hline Dep. Var. Mean & 0.482 & 0.482 & 0.482 & 0.482 & 0.482 & 0.482 & 0.482 \\
\hline $\mathrm{R}^{2}$ & 0.54 & 0.58 & 0.56 & 0.54 & 0.58 & 0.60 & 0.63 \\
\hline State Fixed Effects & $\checkmark$ & $\checkmark$ & $\checkmark$ & $\checkmark$ & $\checkmark$ & $\checkmark$ & $\checkmark$ \\
\hline Geographic/Agroclimatic Controls & $\checkmark$ & $\checkmark$ & $\checkmark$ & $\checkmark$ & $\checkmark$ & $\checkmark$ & $\checkmark$ \\
\hline
\end{tabular}

Notes: This table reports estimates of equation (2) for the main mask use outcome while accounting for potential confounders at the county level. The regressions control for state fixed effects and the following additional predetermined controls: county area; county centroid latitude and longitude; distance to oceans,lakes and rivers from county centroid; mean county rainfall; elevation; and average potential agricultural yield. Standard errors are clustered by arbitrary 60square-mile grid cells. Standard errors are clustered by arbitrary 60 -square-mile grid cells.

Significance levels: $*: 10 \% \quad * *: 5 \% \quad * * *: 1 \%$. 
Table A.3: Robustness Checks: TFE and Local Policies (I)

\begin{tabular}{|c|c|c|c|c|c|c|c|}
\hline & $(1)$ & $(2)$ & (3) & $(4)$ & $(5)$ & (6) & $(7)$ \\
\hline & \multicolumn{7}{|c|}{ (a) County Policies: Emergency Declarations } \\
\hline total frontier experience & $\begin{array}{c}-0.042^{* * *} \\
(0.011)\end{array}$ & $\begin{array}{c}-0.025^{* *} \\
(0.011)\end{array}$ & $\begin{array}{c}-0.035^{* * *} \\
(0.011)\end{array}$ & $\begin{array}{c}-0.042^{* * *} \\
(0.011)\end{array}$ & $\begin{array}{c}-0.030^{* * *} \\
(0.010)\end{array}$ & $\begin{array}{c}-0.023^{* *} \\
(0.011)\end{array}$ & $\begin{array}{l}-0.013 \\
(0.010)\end{array}$ \\
\hline pop. density & & $\begin{array}{c}0.000^{* * *} \\
(0.000)\end{array}$ & & & & & $\begin{array}{c}0.000^{* * *} \\
(0.000)\end{array}$ \\
\hline share white & & & $\begin{array}{c}-0.003^{* * *} \\
(0.001)\end{array}$ & & & & $\begin{array}{c}-0.002^{* * *} \\
(0.001)\end{array}$ \\
\hline temperature & & & & $\begin{array}{c}-0.013 \\
(0.021)\end{array}$ & & & $\begin{array}{l}-0.032^{*} \\
(0.017)\end{array}$ \\
\hline median income & & & & & $\begin{array}{c}0.000^{* * *} \\
(0.000)\end{array}$ & & $\begin{array}{c}0.000^{* * *} \\
(0.000)\end{array}$ \\
\hline share post-sec. educ & & & & & & $\begin{array}{c}0.012^{* * *} \\
(0.001)\end{array}$ & $\begin{array}{c}0.005^{* * *} \\
(0.002)\end{array}$ \\
\hline Number of Counties & 2,036 & 2,036 & 2,036 & 2,036 & 2,036 & 2,036 & 2,036 \\
\hline Dep. Var. Mean & 0.236 & 0.236 & 0.236 & 0.236 & 0.236 & 0.236 & 0.236 \\
\hline $\mathrm{R}^{2}$ & 0.20 & 0.24 & 0.20 & 0.20 & 0.23 & 0.24 & 0.27 \\
\hline State Fixed Effects & $\checkmark$ & $\checkmark$ & $\checkmark$ & $\checkmark$ & $\checkmark$ & $\checkmark$ & $\checkmark$ \\
\hline \multirow[t]{2}{*}{ Geographic/Agroclimatic Controls } & $\checkmark$ & $\checkmark$ & $\checkmark$ & $\checkmark$ & $\checkmark$ & $\checkmark$ & $\checkmark$ \\
\hline & \multicolumn{7}{|c|}{ (b) County Policies: Stay at Home Policies } \\
\hline total frontier experience & $\begin{array}{c}-0.025^{* * *} \\
(0.007)\end{array}$ & $\begin{array}{c}-0.014^{* *} \\
(0.006)\end{array}$ & $\begin{array}{c}-0.021^{* * *} \\
(0.007)\end{array}$ & $\begin{array}{c}-0.025^{* * *} \\
(0.007)\end{array}$ & $\begin{array}{c}-0.019^{* * *} \\
(0.006)\end{array}$ & $\begin{array}{c}-0.014^{* *} \\
(0.006)\end{array}$ & $\begin{array}{l}-0.009 \\
(0.006)\end{array}$ \\
\hline pop. density & & $\begin{array}{c}0.000^{* * *} \\
(0.000)\end{array}$ & & & & & $\begin{array}{c}0.000^{* * *} \\
(0.000)\end{array}$ \\
\hline share white & & & $\begin{array}{c}-0.002^{* * *} \\
(0.001)\end{array}$ & & & & $\begin{array}{l}-0.001^{*} \\
(0.000)\end{array}$ \\
\hline temperature & & & & $\begin{array}{l}0.024^{*} \\
(0.014)\end{array}$ & & & $\begin{array}{c}0.012 \\
(0.014)\end{array}$ \\
\hline median income & & & & & $\begin{array}{c}0.000^{* * * *} \\
(0.000)\end{array}$ & & $\begin{array}{l}0.000^{* *} \\
(0.000)\end{array}$ \\
\hline share post-sec. educ & & & & & & $\begin{array}{c}0.007^{* * *} \\
(0.001)\end{array}$ & $\begin{array}{l}0.003^{* *} \\
(0.001)\end{array}$ \\
\hline Number of Counties & 2,036 & 2,036 & 2,036 & 2,036 & 2,036 & 2,036 & 2,036 \\
\hline Dep. Var. Mean & 0.048 & 0.048 & 0.048 & 0.048 & 0.048 & 0.048 & 0.048 \\
\hline $\mathrm{R}^{2}$ & 0.16 & 0.23 & 0.16 & 0.16 & 0.19 & 0.21 & 0.25 \\
\hline State Fixed Effects & $\checkmark$ & $\checkmark$ & $\checkmark$ & $\checkmark$ & $\checkmark$ & $\checkmark$ & $\checkmark$ \\
\hline \multirow[t]{2}{*}{ Geographic/Agroclimatic Controls } & $\checkmark$ & $\checkmark$ & $\checkmark$ & $\checkmark$ & $\checkmark$ & $\checkmark$ & $\checkmark$ \\
\hline & \multicolumn{7}{|c|}{ (c) County Policies: Business Closure Policies } \\
\hline total frontier experience & $\begin{array}{l}-0.003 \\
(0.003)\end{array}$ & $\begin{array}{c}-0.001 \\
(0.003)\end{array}$ & $\begin{array}{l}-0.002 \\
(0.003)\end{array}$ & $\begin{array}{c}-0.003 \\
(0.003)\end{array}$ & $\begin{array}{c}-0.002 \\
(0.003)\end{array}$ & $\begin{array}{c}-0.002 \\
(0.003)\end{array}$ & $\begin{array}{c}-0.001 \\
(0.003)\end{array}$ \\
\hline pop. density & & $\begin{array}{c}0.000 \\
(0.000)\end{array}$ & & & & & $\begin{array}{c}0.000 \\
(0.000)\end{array}$ \\
\hline share white & & & $\begin{array}{l}-0.000 \\
(0.000)\end{array}$ & & & & $\begin{array}{l}-0.000 \\
(0.000)\end{array}$ \\
\hline temperature & & & & $\begin{array}{c}0.001 \\
(0.003)\end{array}$ & & & $\begin{array}{l}-0.001 \\
(0.003)\end{array}$ \\
\hline median income & & & & & $\begin{array}{c}0.000 \\
(0.000)\end{array}$ & & $\begin{array}{c}0.000 \\
(0.000)\end{array}$ \\
\hline share post-sec. educ & & & & & & $\begin{array}{l}0.001^{*} \\
(0.000)\end{array}$ & $\begin{array}{c}0.000 \\
(0.000)\end{array}$ \\
\hline Number of Counties & 2,036 & 2,036 & 2,036 & 2,036 & 2,036 & 2,036 & 2,036 \\
\hline Dep. Var. Mean & 0.006 & 0.006 & 0.006 & 0.006 & 0.006 & 0.006 & 0.006 \\
\hline $\mathrm{R}^{2}$ & 0.06 & 0.07 & 0.06 & 0.06 & 0.06 & 0.06 & 0.07 \\
\hline State Fixed Effects & $\checkmark$ & $\checkmark$ & $\checkmark$ & $\checkmark$ & $\checkmark$ & $\checkmark$ & $\checkmark$ \\
\hline Geographic/Agroclimatic Controls & $\checkmark$ & $\checkmark$ & $\checkmark$ & $\checkmark$ & $\checkmark$ & $\checkmark$ & $\checkmark$ \\
\hline
\end{tabular}

Notes: This table reports estimates of equation (2) for local policy outcomes while accounting for potential confounders at the county level. The regressions control for state fixed effects and the following additional predetermined controls: county area; county centroid latitude and longitude; distance to oceans,lakes and rivers from county centroid; mean county rainfall; elevation; and average potential agricultural yield. Standard errors are clustered by arbitrary 60-squaremile grid cells. Standard errors are clustered by arbitrary 60-square-mile grid cells.

Significance levels: $*: 10 \% * *: 5 \% * * *: 1 \%$. 
Table A.4: Robustness Checks: TFE and Local Policies (II)

\begin{tabular}{|c|c|c|c|c|c|c|c|}
\hline & $(1)$ & (2) & (3) & (4) & (5) & (6) & (7) \\
\hline & \multicolumn{7}{|c|}{ (d) County Policies: Mask Mandates } \\
\hline total frontier experience & $\begin{array}{c}-0.036^{* * *} \\
(0.008)\end{array}$ & $\begin{array}{c}-0.025^{* * *} \\
(0.008)\end{array}$ & $\begin{array}{c}-0.028^{* * *} \\
(0.008)\end{array}$ & $\begin{array}{c}-0.037^{* * *} \\
(0.008)\end{array}$ & $\begin{array}{c}-0.030^{* * *} \\
(0.008)\end{array}$ & $\begin{array}{c}-0.019^{* *} \\
(0.008)\end{array}$ & $\begin{array}{l}-0.012 \\
(0.008)\end{array}$ \\
\hline pop. density & & $\begin{array}{c}0.000^{* * *} \\
(0.000)\end{array}$ & & & & & $\begin{array}{c}0.000 \\
(0.000)\end{array}$ \\
\hline share white & & & $\begin{array}{c}-0.004^{* * *} \\
(0.001)\end{array}$ & & & & $\begin{array}{c}-0.003^{* * *} \\
(0.001)\end{array}$ \\
\hline temperature & & & & $\begin{array}{l}-0.031 \\
(0.020)\end{array}$ & & & $\begin{array}{c}-0.043^{* *} \\
(0.017)\end{array}$ \\
\hline median income & & & & & $\begin{array}{c}0.000^{* * *} \\
(0.000)\end{array}$ & & $\begin{array}{l}-0.000 \\
(0.000)\end{array}$ \\
\hline share post-sec. educ & & & & & & $\begin{array}{c}0.012^{* * *} \\
(0.001)\end{array}$ & $\begin{array}{c}0.011^{* * *} \\
(0.002)\end{array}$ \\
\hline Number of Counties & 2,035 & 2,035 & 2,035 & 2,035 & 2,035 & 2,035 & 2,035 \\
\hline Dep. Var. Mean & 0.405 & 0.405 & 0.405 & 0.405 & 0.405 & 0.405 & 0.405 \\
\hline $\mathrm{R}^{2}$ & 0.61 & 0.63 & 0.62 & 0.61 & 0.62 & 0.64 & 0.65 \\
\hline State Fixed Effects & $\checkmark$ & $\checkmark$ & $\checkmark$ & $\checkmark$ & $\checkmark$ & $\checkmark$ & $\checkmark$ \\
\hline Geographic/Agroclimatic Controls & $\checkmark$ & $\checkmark$ & $\checkmark$ & $\checkmark$ & $\checkmark$ & $\checkmark$ & $\checkmark$ \\
\hline
\end{tabular}

Notes: This table reports estimates of equation (2) for local policy outcomes while accounting for potential confounders at the county level. The regressions control for state fixed effects and the following additional predetermined controls: county area; county centroid latitude and longitude; distance to oceans,lakes and rivers from county centroid; mean county rainfall; elevation; and average potential agricultural yield. Standard errors are clustered by arbitrary $60-$ squaremile grid cells. Standard errors are clustered by arbitrary 60 -square-mile grid cells.

Significance levels: $*: 10 \% \quad * *: 5 \% \quad * * *: 1 \%$. 
Table A.5: Disentangling Population Density: TFE, Social Distancing, and Mask Use

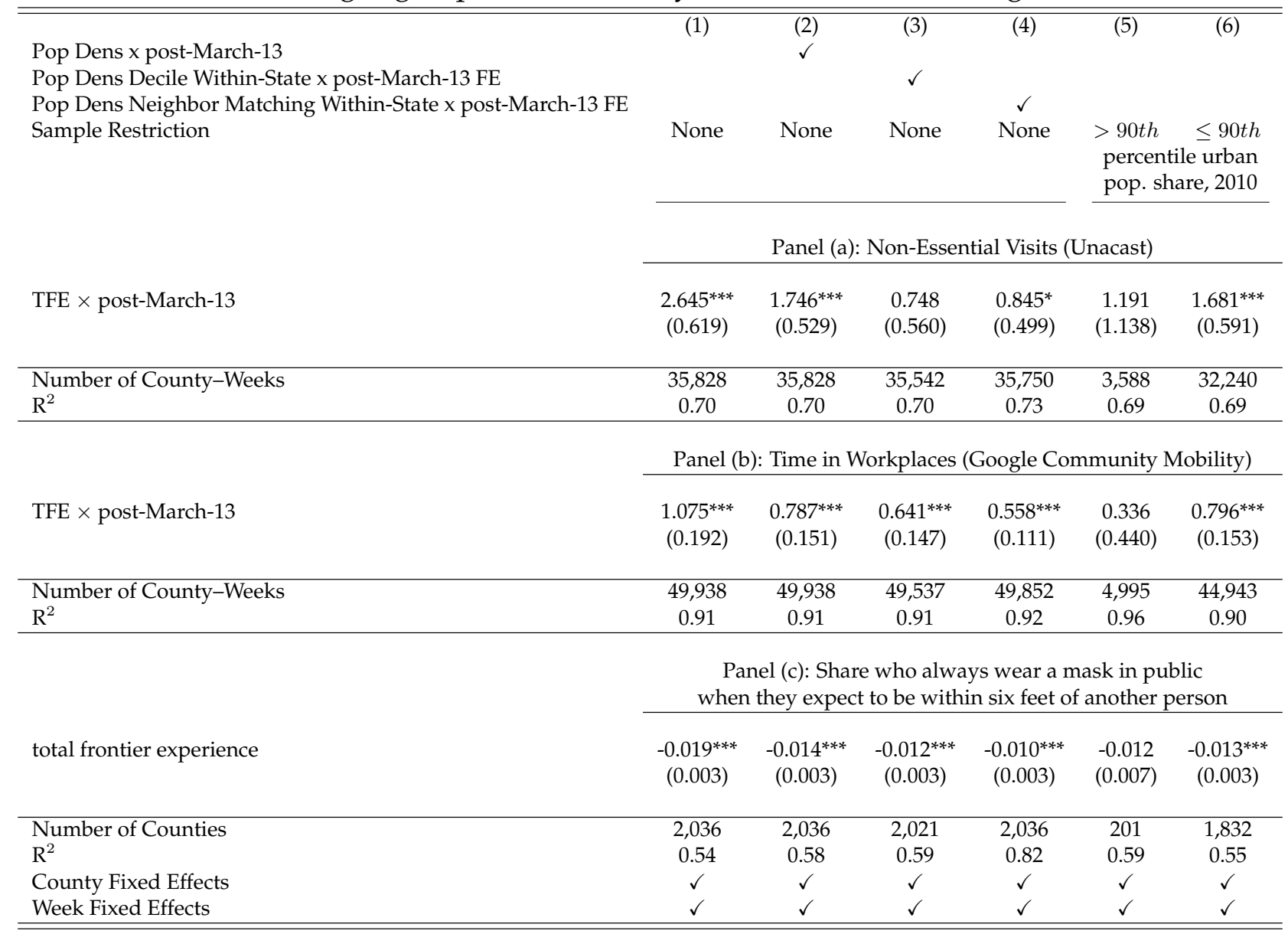

Notes: This table disentangles the effects of TFE on social distancing outcomes from the effects of contemporary population density by controlling for the differential effects of population density in several ways. Column 1 reports the baseline estimates with county and week fixed effects. Column 2 adds an interaction of the 2010 population density with postMarch 13 indicator. Column 3 includes fixed effect for the decile of within-state population density interacted with week indicators. Column 4 includes fixed effects indicators within-state pairs of counties that have the most similar population density in 2010 interacted with week indicators. Columns 5 and 6 split the sample into counties above and below the 90 th percentile of contemporaneous urban population shares. Standard errors are clustered by arbitrary 60-square-mile grid cells. Column 4 and 5 additionally cluster (two-way) on the population density deciles and within-state county-pairs, respectively.

Significance levels: $*: 10 \% \quad * *: 5 \% \quad * * *: 1 \%$. 
Table A.6: Disentangling Population Density: TFE and Local Policies

\begin{tabular}{|c|c|c|c|c|c|c|}
\hline \multirow{5}{*}{$\begin{array}{l}\text { Pop Dens x post-March-13 } \\
\text { Pop Dens Decile Within-State x post-March-13 FE } \\
\text { Pop Dens Neighbor Matching Within-State x post-March-13 FE } \\
\text { Sample Restriction }\end{array}$} & $\overline{(1)}$ & $\overline{(2)}$ & (3) & $(4)$ & $(5)$ & $(6)$ \\
\hline & & $\checkmark$ & & & & \\
\hline & & & $\checkmark$ & & & \\
\hline & & & & $\checkmark$ & & \\
\hline & None & None & None & None & $\begin{array}{l}>90 t h \\
\text { percenti } \\
\text { pop. sha }\end{array}$ & $\begin{array}{r}\leq 90 t h \\
\text { le urban } \\
\text { are, } 2010\end{array}$ \\
\hline \multirow[b]{2}{*}{ total frontier experience } & \multicolumn{6}{|c|}{ (a): Emergency Declaration } \\
\hline & $\begin{array}{c}-0.042^{* * *} \\
(0.011)\end{array}$ & $\begin{array}{c}-0.025^{* *} \\
(0.011)\end{array}$ & $\begin{array}{l}-0.017 \\
(0.011)\end{array}$ & $\begin{array}{c}-0.022 \\
(0.014)\end{array}$ & $\begin{array}{c}0.025 \\
(0.035)\end{array}$ & $\begin{array}{l}-0.021^{*} \\
(0.012)\end{array}$ \\
\hline Number of Counties & 2,036 & 2,036 & 2,021 & 2,036 & 201 & 1,832 \\
\hline $\mathrm{R}^{2}$ & 0.20 & 0.24 & 0.25 & 0.63 & 0.27 & 0.20 \\
\hline \multirow[b]{2}{*}{ total frontier experience } & \multicolumn{6}{|c|}{ (b): Stay at Home Policies } \\
\hline & $\begin{array}{c}-0.025^{* * *} \\
(0.007)\end{array}$ & $\begin{array}{c}-0.014^{* *} \\
(0.006)\end{array}$ & $\begin{array}{l}-0.012^{*} \\
(0.006)\end{array}$ & $\begin{array}{c}-0.012^{*} \\
(0.007)\end{array}$ & $\begin{array}{c}-0.051^{*} \\
(0.029)\end{array}$ & $\begin{array}{l}-0.009 \\
(0.006)\end{array}$ \\
\hline Number of Counties & 2,036 & 2,036 & 2,021 & 2,036 & 201 & 1,832 \\
\hline $\mathrm{R}^{2}$ & 0.16 & 0.23 & 0.25 & 0.69 & 0.48 & 0.13 \\
\hline \multirow[b]{2}{*}{ total frontier experience } & \multicolumn{6}{|c|}{ (c): Business Closure Policies } \\
\hline & $\begin{array}{l}-0.003 \\
(0.003)\end{array}$ & $\begin{array}{l}-0.001 \\
(0.003)\end{array}$ & $\begin{array}{c}-0.001 \\
(0.003)\end{array}$ & $\begin{array}{c}0.000 \\
(0.004)\end{array}$ & $\begin{array}{c}0.040 \\
(0.029)\end{array}$ & $\begin{array}{l}-0.003^{*} \\
(0.002)\end{array}$ \\
\hline Number of Counties & 2,036 & 2,036 & 2,021 & 2,036 & 201 & 1,832 \\
\hline $\mathrm{R}^{2}$ & 0.06 & 0.07 & 0.06 & 0.52 & 0.23 & 0.04 \\
\hline \multirow[b]{2}{*}{ total frontier experience } & \multicolumn{6}{|c|}{ (d): Mask Mandates } \\
\hline & $\begin{array}{c}-0.036^{* * *} \\
(0.008)\end{array}$ & $\begin{array}{c}-0.025^{* * *} \\
(0.008)\end{array}$ & $\begin{array}{c}-0.019^{* *} \\
(0.008)\end{array}$ & $\begin{array}{c}-0.022^{* *} \\
(0.010)\end{array}$ & $\begin{array}{c}-0.037 \\
(0.036)\end{array}$ & $\begin{array}{c}-0.018^{* *} \\
(0.008)\end{array}$ \\
\hline Number of Counties & 2,035 & 2,035 & 2,020 & 2,035 & 201 & 1,831 \\
\hline $\mathrm{R}^{2}$ & 0.61 & 0.63 & 0.65 & 0.83 & 0.44 & 0.67 \\
\hline State Fixed Effects & $\checkmark$ & $\checkmark$ & $\checkmark$ & $\checkmark$ & $\checkmark$ & $\checkmark$ \\
\hline Geographic/Agroclimatic Controls & $\checkmark$ & $\checkmark$ & $\checkmark$ & $\checkmark$ & $\checkmark$ & $\checkmark$ \\
\hline
\end{tabular}

Notes: This table disentangles the effects of TFE on local policies from the effects of contemporary population density in several ways. Column 1 reports the baseline with state fixed effects and geographic and agroclimatic controls. Column 2 controls for contemporaneous population density. Column 3 includes fixed effects for the decile of within-state population density. Column 4 included fixed effects for the nearest-neighbor matching based on 2010 population density. Columns 5 and 6 split the sample into counties above and below the 90th percentile of contemporaneous urban population shares. The regressions control for state fixed effects and the following additional predetermined controls: county area; county centroid latitude and longitude; distance to oceans,lakes and rivers from county centroid; mean county rainfall; elevation; and average potential agricultural yield. Standard errors are clustered by arbitrary 60-square-mile grid cells. Standard errors are clustered by arbitrary 60-square-mile grid cells. Column 4 and 5 additionally cluster (two-way) on the population density deciles and within-state county-pairs, respectively.

Significance levels: $*: 10 \% \quad * *: 5 \% \quad * * *: 1 \%$. 


\section{Table A.7: Adding West Coast, Extended Time Frame, Regional Heterogeneity TFE, Social Distancing, and Mask Use}

\begin{tabular}{|c|c|c|c|c|c|c|c|c|}
\hline \multirow{2}{*}{$\begin{array}{l}\text { Frontier Time Frame: } \\
\text { Regional Sample Restriction: }\end{array}$} & \multicolumn{4}{|c|}{ Baseline (1790-1890) } & \multicolumn{4}{|c|}{ Extended (1790-1950) } \\
\hline & $\begin{array}{l}\text { Baseline }+ \\
\text { West Coast } \\
\text { (1) }\end{array}$ & $\begin{array}{c}\text { Only } \\
\text { Midwest } \\
(2)\end{array}$ & $\begin{array}{l}\text { Only } \\
\text { South } \\
(3)\end{array}$ & $\begin{array}{c}\text { Only } \\
\text { West } \\
(4)\end{array}$ & $\begin{array}{l}\text { Extended } \\
\text { Sample } \\
\text { (5) }\end{array}$ & $\begin{array}{c}\text { Only } \\
\text { Midwest } \\
(6)\end{array}$ & $\begin{array}{l}\text { Only } \\
\text { South } \\
(7)\end{array}$ & $\begin{array}{l}\text { Only } \\
\text { West } \\
(8)\end{array}$ \\
\hline \multirow[b]{2}{*}{ TFE $\times$ post-March-13 } & \multicolumn{8}{|c|}{ (a): Non-Essential Visits (Unacast) } \\
\hline & $\begin{array}{l}1.036^{* *} \\
(0.466)\end{array}$ & $\begin{array}{l}3.338^{* *} \\
(1.408)\end{array}$ & $\begin{array}{c}0.519 \\
(0.409)\end{array}$ & $\begin{array}{l}-1.959 * \\
(1.010)\end{array}$ & $\begin{array}{l}1.149^{* * *} \\
(0.413)\end{array}$ & $\begin{array}{l}4.581^{* * *} \\
(1.552)\end{array}$ & $\begin{array}{c}0.364 \\
(0.380)\end{array}$ & $\begin{array}{c}0.718 \\
(0.593)\end{array}$ \\
\hline $\begin{array}{l}\text { Number of County-Weeks } \\
\mathrm{R}^{2}\end{array}$ & $\begin{array}{c}38,168 \\
0.04 \\
\end{array}$ & $\begin{array}{c}15,106 \\
0.01 \\
\end{array}$ & $\begin{array}{c}18,460 \\
0.03 \\
\end{array}$ & $\begin{array}{c}3,120 \\
0.07 \\
\end{array}$ & $\begin{array}{c}42,926 \\
0.03 \\
\end{array}$ & $\begin{array}{c}15,340 \\
0.02 \\
\end{array}$ & $\begin{array}{c}20,410 \\
0.03 \\
\end{array}$ & $\begin{array}{c}5,694 \\
0.08 \\
\end{array}$ \\
\hline \multirow[b]{2}{*}{ TFE $\times$ post-March-13 } & \multicolumn{8}{|c|}{ (b): Time in Workplaces (Google Community Mobility) } \\
\hline & $\begin{array}{l}-4.021^{* * *} \\
(0.239)\end{array}$ & $\begin{array}{c}-5.909^{* * *} \\
(0.339)\end{array}$ & $\begin{array}{c}-3.056^{* * *} \\
(0.265)\end{array}$ & $\begin{array}{c}-3.603^{* * *} \\
(0.665)\end{array}$ & $\begin{array}{c}-2.778^{* * *} \\
(0.212)\end{array}$ & $\begin{array}{c}-5.212^{* * *} \\
(0.423)\end{array}$ & $\begin{array}{l}-2.794^{* * *} \\
(0.208)\end{array}$ & $\begin{array}{c}-1.508^{* * *} \\
(0.218)\end{array}$ \\
\hline $\begin{array}{l}\text { Number of County-Weeks } \\
\mathrm{R}^{2}\end{array}$ & $\begin{array}{c}52,615 \\
0.15\end{array}$ & $\begin{array}{c}23,275 \\
0.19\end{array}$ & $\begin{array}{c}23,884 \\
0.12\end{array}$ & $\begin{array}{c}3,757 \\
0.09\end{array}$ & $\begin{array}{c}59,965 \\
0.12\end{array}$ & $\begin{array}{c}23,681 \\
0.17\end{array}$ & $\begin{array}{c}26,696 \\
0.12\end{array}$ & $\begin{array}{c}7,889 \\
0.10\end{array}$ \\
\hline \multirow[b]{2}{*}{ total frontier experience } & \multicolumn{8}{|c|}{$\begin{array}{l}\text { (c): Share who always wear a mask in public } \\
\text { when they expect to be within six feet of another person }\end{array}$} \\
\hline & $\begin{array}{l}-0.019^{* * *} \\
(0.003)\end{array}$ & $\begin{array}{c}-0.031^{* * *} \\
(0.006)\end{array}$ & $\begin{array}{l}-0.018^{* * *} \\
(0.004)\end{array}$ & $\begin{array}{l}-0.002 \\
(0.009)\end{array}$ & $\begin{array}{c}-0.012^{* * *} \\
(0.002)\end{array}$ & $\begin{array}{l}-0.016^{* * *} \\
(0.006)\end{array}$ & $\begin{array}{l}-0.015^{* * *} \\
(0.003)\end{array}$ & $\begin{array}{l}-0.005^{*} \\
(0.003)\end{array}$ \\
\hline Number of Counties & 2,141 & 987 & 936 & 152 & 2,499 & 1,037 & 1,074 & 322 \\
\hline $\mathrm{R}^{2}$ & 0.58 & 0.40 & 0.44 & 0.55 & 0.59 & 0.42 & 0.46 & 0.72 \\
\hline County or State Fixed Effects & $\checkmark$ & $\checkmark$ & $\checkmark$ & $\checkmark$ & $\checkmark$ & $\checkmark$ & $\checkmark$ & $\checkmark$ \\
\hline Week FE & $\checkmark$ & $\checkmark$ & $\checkmark$ & $\checkmark$ & $\checkmark$ & $\checkmark$ & $\checkmark$ & $\checkmark$ \\
\hline Geographic/Agroclimatic Controls & $\checkmark$ & $\checkmark$ & $\checkmark$ & $\checkmark$ & $\checkmark$ & $\checkmark$ & $\checkmark$ & $\checkmark$ \\
\hline
\end{tabular}

Notes: Focusing on the key social distancing outcomes, this table extends our baseline sample of counties and examines region-by-region sample splits. Column 1 adds counties along the secondary West Coast frontier. Column 2 restricts to counties in the Midwest Census region, column 3 restricts to the South region, and column 4 restricts to the West, which includes the counties added in column 1 plus others in states in the West region but falling inside the 1890 main east-towest frontier line. Column 5 expands the column 1 sample to include counties beyond the (main and secondary) 1890 frontier lines but inside the eventual frontier line realized by 1950 . Columns 6-8 then proceed with the same region-byregion sample splits. Standard errors are clustered by arbitrary 60-square-mile grid cells.

Significance levels: $*: 10 \% \quad * *: 5 \% \quad * * *: 1 \%$. 


\section{Table A.8: Adding West Coast, Extended Time Frame, Regional Heterogeneity}

\section{TFE and Local Policies}

\begin{tabular}{|c|c|c|c|c|c|c|c|c|}
\hline \multirow{2}{*}{$\begin{array}{l}\text { Frontier Time Frame: } \\
\text { Regional Sample Restriction: }\end{array}$} & \multicolumn{4}{|c|}{ Baseline (1790-1890) } & \multicolumn{4}{|c|}{ Extended (1790-1950) } \\
\hline & $\begin{array}{c}\text { Baseline }+ \\
\text { West Coast } \\
\text { (1) }\end{array}$ & $\begin{array}{c}\text { Only } \\
\text { Midwest } \\
\text { (2) }\end{array}$ & $\begin{array}{l}\text { Only } \\
\text { South } \\
(3)\end{array}$ & $\begin{array}{c}\text { Only } \\
\text { West } \\
(4)\end{array}$ & $\begin{array}{c}\text { Extended } \\
\text { Sample } \\
(5)\end{array}$ & $\begin{array}{c}\text { Only } \\
\text { Midwest } \\
\text { (6) }\end{array}$ & $\begin{array}{l}\text { Only } \\
\text { South } \\
(7)\end{array}$ & $\begin{array}{c}\text { Only } \\
\text { West } \\
(8)\end{array}$ \\
\hline \multirow[b]{2}{*}{ total frontier experience } & \multicolumn{8}{|c|}{ (a): Emergency Declaration } \\
\hline & $\begin{array}{c}-0.039 * * * \\
(0.011)\end{array}$ & $\begin{array}{c}-0.060^{* * *} \\
(0.018)\end{array}$ & $\begin{array}{c}-0.039^{* * *} \\
(0.015)\end{array}$ & $\begin{array}{c}0.023 \\
(0.026)\end{array}$ & $\begin{array}{c}-0.020^{* * *} \\
(0.007)\end{array}$ & $\begin{array}{c}-0.041^{* * *} \\
(0.014)\end{array}$ & $\begin{array}{c}-0.027^{* * *} \\
(0.010)\end{array}$ & $\begin{array}{l}-0.004 \\
(0.010)\end{array}$ \\
\hline Number of Counties & 2,141 & 987 & 936 & 152 & 2,500 & 1,038 & 1,074 & 322 \\
\hline $\mathrm{R}^{2}$ & 0.26 & 0.10 & 0.19 & 0.45 & 0.28 & 0.09 & 0.19 & 0.42 \\
\hline \multirow[b]{2}{*}{ total frontier experience } & \multicolumn{8}{|c|}{ (b): Stay at Home Policies } \\
\hline & $\begin{array}{c}-0.027^{* * *} \\
(0.007)\end{array}$ & $\begin{array}{l}-0.013 \\
(0.010)\end{array}$ & $\begin{array}{c}-0.027^{* * *} \\
(0.008)\end{array}$ & $\begin{array}{l}-0.034 \\
(0.023)\end{array}$ & $\begin{array}{c}-0.021^{* * *} \\
(0.004)\end{array}$ & $\begin{array}{l}-0.005 \\
(0.009)\end{array}$ & $\begin{array}{c}-0.029^{* * *} \\
(0.006)\end{array}$ & $\begin{array}{c}-0.018^{* * *} \\
(0.005)\end{array}$ \\
\hline Number of Counties & 2,141 & 987 & 936 & 152 & 2,500 & 1,038 & 1,074 & 322 \\
\hline $\mathrm{R}^{2}$ & 0.24 & 0.12 & 0.16 & 0.50 & 0.22 & 0.12 & 0.16 & 0.40 \\
\hline \multirow[b]{2}{*}{ total frontier experience } & \multicolumn{8}{|c|}{ (c): Business Closure Policies } \\
\hline & $\begin{array}{l}-0.002 \\
(0.003)\end{array}$ & $\begin{array}{l}-0.002 \\
(0.002)\end{array}$ & $\begin{array}{l}-0.002 \\
(0.004)\end{array}$ & $\begin{array}{c}0.012 \\
(0.011)\end{array}$ & $\begin{array}{c}-0.004^{* *} \\
(0.002)\end{array}$ & $\begin{array}{l}-0.001 \\
(0.002)\end{array}$ & $\begin{array}{l}-0.003 \\
(0.003)\end{array}$ & $\begin{array}{l}-0.004 \\
(0.003)\end{array}$ \\
\hline Number of Counties & 2,141 & 987 & 936 & 152 & 2,500 & 1,038 & 1,074 & 322 \\
\hline $\mathrm{R}^{2}$ & 0.09 & 0.02 & 0.08 & 0.35 & 0.11 & 0.02 & 0.07 & 0.22 \\
\hline \multirow[b]{2}{*}{ total frontier experience } & \multicolumn{8}{|c|}{ (d): Mask Mandates } \\
\hline & $\begin{array}{c}-0.004^{* * *} \\
(0.001)\end{array}$ & $\begin{array}{l}-0.000 \\
(0.004)\end{array}$ & $\begin{array}{c}-0.002^{* *} \\
(0.001)\end{array}$ & $\begin{array}{l}-0.008 \\
(0.011)\end{array}$ & $\begin{array}{l}-0.003 \\
(0.002)\end{array}$ & $\begin{array}{l}-0.000 \\
(0.004)\end{array}$ & $\begin{array}{l}-0.003^{* *} \\
(0.001)\end{array}$ & $\begin{array}{c}0.000 \\
(0.003)\end{array}$ \\
\hline Number of Counties & 1,307 & 349 & 771 & 136 & 1,494 & 351 & 827 & 265 \\
\hline $\mathrm{R}^{2}$ & 0.10 & 0.03 & 0.05 & 0.44 & 0.09 & 0.03 & 0.05 & 0.25 \\
\hline State Fixed Effects & $\checkmark$ & $\checkmark$ & $\checkmark$ & $\checkmark$ & $\checkmark$ & $\checkmark$ & $\checkmark$ & $\checkmark$ \\
\hline Geographic/Agroclimatic Controls & $\checkmark$ & $\checkmark$ & $\checkmark$ & $\checkmark$ & $\checkmark$ & $\checkmark$ & $\checkmark$ & $\checkmark$ \\
\hline
\end{tabular}

Notes: Focusing on the local policy outcomes, this table extends our baseline sample of counties and examines region-byregion sample splits. Column 1 adds counties along the secondary West Coast frontier. Column 2 restricts to counties in the Midwest Census region, column 3 restricts to the South region, and column 4 restricts to the West, which includes the counties added in column 1 plus others in states in the West region but falling inside the 1890 main east-to-west frontier line. Column 5 expands the column 1 sample to include counties beyond the (main and secondary) 1890 frontier lines but inside the eventual frontier line realized by 1950. Columns 6-8 then proceed with the same region-by-region sample splits. The regressions control for state fixed effects and the following additional predetermined controls: county area; county centroid latitude and longitude; distance to oceans,lakes and rivers from county centroid; mean county rainfall; elevation; and average potential agricultural yield. Standard errors are clustered by arbitrary 60-square-mile grid cells. Standard errors are clustered by arbitrary 60-square-mile grid cells.

Significance levels: $*: 10 \% \quad * *: 5 \% \quad * * *: 1 \%$. 